\title{
Râbıtanın Tarihî Gelişimi, Tanımı ve Fıkhî Hükmü
}

Historical Development of Rābıța, Definition and its Hukm According to Fiqh

Dr. Öğr. Üyesi

\section{Akif DURSUN}

$\begin{array}{ll}\square+a & \text { İstanbul Medeniyet Üniversitesi, Hukuk Fakültesi } \\ & \text { orcid.org/0000-0001-5392-2162 } \\ & \text { akifdursun@gmail.com }\end{array}$




\section{Sufinge}

84

\section{Öz}

Başkasıyla kurulan bağ anlamına gelen râbıta tarikat ehli tarafından mürşitle bağlantı kurmak mânasında kullanılmıştır. Râbıta Nakşibendîler ile özdeşleştirilmekte ve genel olarak onlar tarafından başlatıldığı kabul edilmekteyse de yaptı̆̆ımız araştırma bunun tam olarak doğruyu aksettirmediğini göstermektedir. Nakşîbendiler haricinde de çok sayıda tarikatta bilinen ve uygulanan mürşit râbıtası ilk dönemlerde şeyhe muhabbet duymak ve onu örnek almak şeklinde başlamış, daha sonra şeyhin sûretini ve ondan feyz geldiğini düşünmeye evrilmiştir. İlk zamanlarda özel bir ders olarak verilmeyip sadece belli başlı müritlere tavsiye edilirken daha sonraki dönemlerde tasavvufî hayata yeni girenlere verilen bir ders haline dönüşmüş, pek çok tarikat ehli tarafından seyr u sülûkün en esaslı yollarından biri olarak kabul edilmiştir. Bu durum zamanla abartılmış, havâtırı def etmek gerekçesi ile namaz ve zikir esnasında da şeyhin düşünülmesini isteyenler çıkmıştır. Bu da bazı âlimlerin tepkisini çekmiş ve râbıta aleyhinde söz söylemelerine, reddiye mâhiyetinde risâleler yazmalarına neden olmuştur. Buna mukâbil râbıta aleyhine yapılan konuşmalar, yazılan eserler de râbıtayı savunmak amacıyla birçok eser telif edilmesine yol açmıştır. Özellikle son iki yüzyılda yapılan bu tartışmalar halen devam etmektedir. Genellikle tasavvuf ehli ile bunlara karşı olanlar arasındaki bu tartışma birbirini ithama varacak düzeydedir. Biz bu makalemizde râbıta konusunu İslâm fikhı açısından incelemeye gayret edeceğiz. Bunu yaparken öncelikle tasavvuf kaynaklarından istifade ile râbıtanın tarihî gelişimi, tanımı ve çeşitlerini anlatacağız. Ardından râbıtayı savunanlarla karşı çıkanların delillerini ortaya koyarak değerlendirecek, sonunda da râbıtanın çeşitlerine göre hükmünü ortaya koymaya çalışacağız.

Anahtar Kelimeler: Fıkıh, Tasavvuf, Tarikat, Nakşîbendiyye, Râbıta, Şeyh, Şirk.

\section{Abstract}

The term "rābıṭa" is used for "the binding of the disciple with a șûfĩ master" by șūfīs. Although rābița is identified with the Naqshbandī and generally accepted that it was initiated by this order, our research indicates that this does not fully reflect the truth. The rābita of mursheed is known and practiced in many orders apart from the Naqshbandi order, firstly started as a love of the shaikh and taking him as an example, then evolved into thinking of the shaikh's image and to be enlightened by him. It was recommended only to some disciples at first, but then it turned into a lesson given to the beginners and accepted as one of the fundamental ways of sayr'u-sulūk. As a result of exaggeration, some people stipulated to think of the shaikh during the prayer or dhikr to banish khavāṭr. It drew the reaction of some scholars and prompted them to write against rābıța. The speeches and writings against rābıța led scholars to do some works to defend it. These debates between șüfĩ and the opponents, which continue for two centuries, reach a level of dismissing each other. This article examines the term rābița in terms of Islamic fiqh. Regarding this, we will explain the definition, development, and types of rābıța from tașawwuf sources. Finding out the evidence of those who defend and oppose rābița, we make an evaluation and finally establish its legal ruling according to the types of rābıța.

Keywords: Fiqh, Taṣawwuf, Țarīqah, Naqshbandī, Rābıța, Shaikh, Shirk. 


\section{Giriş}

Takşibendîlerle özdeşleştirilen ancak çok sayıda tarikatın benimsedi-

- ğ gŭitim metotlarından biri kabul edilen mürşit râbıtası ${ }^{1}$ hakkında son iki yüzyılda çok çeşitli tartışmalar yapılmıştır. Halen de bu tartışmalar genellikle tasavvuf ehli ile bunlara karşı olanlar arasında, birbirini ithama varacak düzeyde devam etmektedir. Fıkıh ilmiyle uğraşanlar ve fakihler genellikle bu tartışmaya çok katılmamışlardır. Günümüzde de az sayıda istisna haricinde fıkıh uzmanları tarafından bu konu çok fazla tartışma ve değerlendirme konusu yapılmamaktadır.

Biz bu makalede temel olarak râbıtanın fikhî hükmünü incelemeye gayret ettik. Bunu yaparken, ilmî metotlara dikkat ederek, öncelikle ulaşabildiğimiz ve önemli gördüğümüz ilgili eserlerden râbıtadan ne kastedildiğini, tarihçesini ve çeşitlerini tespit etmeye çalıştık. Olabildiğince ilk kaynaklara ulaşmak için gayret gösterdik. Sonra râbıta leh ve aleyhindeki delilleri vererek bunları değerlendirmeye tâbi tuttuk ve râbıtanın çeşitleri hakkındaki hükümleri ortaya koymaya çalıştık.

\section{Râbıtanın Târifi, Gelişimi ve Çeşitleri}

Râbıta başta Nakşibendîler olmak üzere tarikat ehli tarafından çok önemsenmiştir. Sühreverdiyye'nin Zeyniyye kolunun kurucusu Zeynüddin Hâfî (ö. 838/1435) feyz hususunda kalbi şeyhe bağlamayı yani râbıtayı büyük bir asıl; hatta asılların aslı görmüştür. Onun aktarmasına göre Kübreviyye tarikatının kurucusu Necmeddîn-i Kübrâ (ö. 618/1221), kalbin şeyhe bağlanmasını (râbıta) ayna yapımında ustaya benzetmiştir. Ayna yapımı için gerekli olan malzeme, usta bulunmadığı zaman bir değer ifade etmez. Aynı şekilde kalp aynası da kalbi şeyhe bağlamadan parlamaz. Bir müridin feyz ve terakkisi kesilmiş ise bu ancak râbıtasının olmamasindandir. ${ }^{2}$

\footnotetext{
1. Bazı müellifler tarafından râbıta için, ölüm râbıtası (râbıta-i mevt), mürşit râbıtası (râbıta-i mürşit) ve huzur râbıtası (râbıta-i huzur) şeklinde üçlü bir tasnif yapılmıştır. bk. İrfan Gündüz, “Tasavvufî Bir Terim Olarak Râbıta”, Tasavvuf İlmî ve Akademik Araştırma Dergisi 19 (2007), 23-53. Ancak râbıta denilince kastedilen ve anlaşılan mürşit râbıtasıdır. Bu sebeple bu makalede sadece mürşit râbıtasından bahsedilecektir.

2. Ebû Bekr Zeynüddîn el-Hâfî, el-Veșâya'l-Oudsiyye (Katar: Dâru'l-Kütübü'l-Katariyye, 5/1/1065), 108b; Bekir Köle, Zeynüddin Hâfî̀ Hayatı Eserleri Tasavvuf Anlayışı ve el-Vasâya'l-Kudsiyye Adlı
} 
İmam Rabbânî̀ye (ö. 1034/1624) göre Allah'a ulaşmada râbita yolundan daha yakın bir yol yoktur. Ubeydullah Ahrâr (ö. 895/1490), delilin (mürşidin) gölgesinin müride Allah’ı zikirden daha fazla fayda vereceğini söylemiştir. Bu sebeple (mübtedî) müridin zikirden çok râbıta ile meşgul olması gerekir. Çünkü bu tam sağlanmadan zikirden istenen fayda tam elde edilemez. ${ }^{3}$

\subsection{Râbıtanın Târifi}

Lügatte "bağlamak" mânasındaki rabt kökünden türeyen râbıta, iki şeyi birbirine bağlayan ip, alâka, bağ, vuslat, münâsebet mânâlarına gelir. Filizlenmesi için saksıya konulmuş ve üzeri sulanmış hurma fidesine "rabît" dendiği gibi, dünyadan el etek çeken zâhîd, hakîm ve râhibe de aynı ad verilir. ${ }^{4}$

Ribât ve murâbata ile aynı kökten gelen ve tasavvufî bir terim olarak kullanılan râbıta kısaca, "sâlikin kâmil bir mürşide gönlünü bağlaması, onun sûret ve sîretini, yani hem yüzünü hem de ahlâk ve davranışlarını düşünmesi” şeklinde târif edilmektedir. ${ }^{5}$

Sûfîler tarafından yapılan râbıtanın ıstılahî tanımlarının tamamı Nakşî şeyhleri veya halifeleri tarafından yapılmıştır. Bu tanımı ilk yapanlardan Tâcüddin b. Zekeriya (ö. 1050/1640) râbıtayı "müşahede makamına varmış ve zâtî sıfatlarla tahakkuk etmiş (Allah’ın sıfatları kendisinde tecelli etmiş) şeyhin sûretini, hayalde muhafaza etmek ve nefiste gaybet ve fenâ oluşana kadar kozalak şeklindeki kalbe yönelmek”6 şeklinde târif etmiştir.

Eserinin Tahkîki (Ankara: Ankara Üniversitesi Sosyal Bilimler Enstitüsü, Yüksek Lisans Tezi, 2001), 145, 219.

3. İmam Rabbânî, Mektubât-ı Rabbânî, çev. Talha Hakan Alp vd. (İstanbul: Yasin Yayınevi, 2004), 1/565-566.

4. Muhammed Murtazâ ez-Zebîdî, Tâcu'l-'arûs min cevâhiri'l-Kâmûs (Beyrut: Dâru'l-Fikr, 2005), 19/298-304; Ebu'l-Fazl Muhammed b. Mükerrem İbn Manzûr, Lisânü’l-Arab (Beyrut: Dâru Sadir, 1414), 7/302.

5. Necdet Tosun, "Râbıta”, Türkiye Diyanet Vakfi İslâm Ansiklopedisi (İstanbul: TDV Yayınları, 2007), 34/378; Ethem Cebecioğlu, Tasavvuf Terimleri ve Deyimleri Sözlüğü (İstanbul: Anka Yayınları, 2005), 507.

6. Abdülganî b. İsmâîl en-Nablusî, Miftâhu'l-ma'iyye fî tarîki'n-Nakşibendiyye, thk. Cevdet Muhammed (Kahire: ed-Dâru'l-Cevdiyye, 1429/2008), 91-94; Hâlid el-Bağdâdî, Risâle fî̀r-Râbıta (Ankara: Milli Kütüphane, Yazmalar Koleksiyonu, 6129/9), 55b. Muhammed Hânî de (ö. 1318/1900) bu tarifi almıştır. bk. Muhammed b. Abdullah el-Hânî, el-Behcetü's-seniyye fî̀ âdâbi't-țarîkati'l-'aliyyeti'l-Hâlidiyyeti’n-Nakşibendiyye (İstanbul: Hakikat Kitabevi, 2016), 71; 
Hâlid-i Bağdâdî̀ye (ö. 1242/1827) göre râbıta, "müridin, fenâ fillâh olmuş kâmil mürşidinin sûretini çokça hatırlayarak ruhaniyetinden istimdad istemesinden ibarettir." Ona göre bu sayede mürit, huzurunda olduğu gibi gıyabında da şeyhine karşı edebini korur, ondan feyz alır, müridin huzûru ve nûru tamamlandığı gibi kötü ve boş işlerden de korunmuş olur. $^{7}$

Muhammed Emîn Kürdî (ö. 1332/1914) tarafından râbıta, "Müridin, kalbini şeyhin kalbine karşı bulundurması; gıyabında bile olsa onun şeklini hayalinde canlandırması; kalbine, şeyhin nur okyanusundan feyzlerin aktığını içinden tasavvur etmesi ve ondan bereket dilemesi”» şeklinde târif edilmiştir.

Ömer Ziyâuddin Dağıstânı̂’nin (ö.1920) râbıta tanımında diğerlerine göre bazı farklılıklar ve fazlalıklar vardır. Ona göre istenen râbıta, “Müridin, tam bir muhabbet ve ihlas ile Allah'ın peygamberlerinden veya velîlerinden veya tamamına veya silsilesi Rasûlullah'a ulaşan birine veya eğer ehlinden ise vasıtasız Rasûlullah'a veya şeyhine veya Allah'ta fani olmuş mürşid-i kâmiline veya tereddütsüz hüsnüzan duyduğu bir zata kalbini bağlamasıdır.” Bunun gereği kişinin râbıta yaptığ kişiden feyz alması, istimdadı, onun sûretini veya ruhâniyetini hayal etmesidir. ${ }^{9}$

Bu târiflerden râbitada en önemli hususun, kalbi şeyhe bağlamak, onun sûretini sıcak ve canlı bir şekilde hayalde tasavvur etmek ve kendini onun yanında düşünmek olduğu anlaşılmaktadır. Sûfîlerin söylediğine göre bu sayede mürit şeyh gibi olacak yani tasavvuf literatüründe 'fenâ fi'ş-şeyh' denilen hale ulaşacak ${ }^{10}$ ve buradan daha öteye geçecektir.

Muhammed b. Abdullah el-Hânî, Âdâb, çev. Ali Hüsrevoğlu (İstanbul: Erkam Yayınları, 1985), 215. Fasihuddîn İbrahim b. Sıbgatillâh Haydârînin (ö. 1300/1882) tanımı da bu minvaldedir: bk. Fasîhuddîn İbrâhîm b. Sıbgatillâh el-Haydarî, el-Mecdü't-tâlid fî̀ menâkıbi'ş-şeyh Hâalid (İstanbul: Matbaa-i Âmire, 1292/1875), 18.

7. Hâlid el-Bağdâdî, Risâle fî̀ r-Râbıta (Yazmalar Koleksiyonu, 6129/9), 53b; Ebu'l-Behâ Ziyâüddîn eş-Şehrezûrî Hâlid el-Bağdâdî, er-Risâletü’l-hâlidiyye fî̀ r-râbitati'n-nakşîbendiyye (es-Sifrü’l-Esnâ kitabının son tarafinda), thk. Abdülcelil 'Atâ (Dımeşk: Dâru’n-Nu'man, 1418/1998), 26.

8. Muhammed Emîn Kürdî, Tenvîru’l-ḳulûb (Haleb: Dâru'l-Kalem, 1411/1991), 571.

9. Ömer Ziyâeddin Dağıstânî, Tasavvufve Tarikatlarla İlgili Fetvalar, çev. İrfan Gündüz - Yakup Çiçek (İstanbul: Seha Neşriyat, 1986), 149-150; Hasan Hilmi Efendi el-Kahî ed-Dağistânî, es-Sifrü'l-esnâ fi'r-râbıtati'l-hüsnâ, thk. Abdülcelil 'Atâ (Dımeşk: Dâru'n-Nu'man, 1418/1998), 6465. “eğer ehlinden ise vasıtasız Rasûlullah'a...” bölümü sadeleştirmede bulunmamakta; Hasan Hilmi'nin eserinde bulunmaktadır.

10. Selçuk Eraydın, Tasavvuf ve Tarikatlar (İstanbul: Marifet Yayınları, 1984), 231. 


\subsection{Râbitanın Tarihî Gelişimi}

İlk dönem tasavvuf kaynaklarında ve sûfîler arasında râbıtanın bugünkü terim kullanımı bilinmemektedir. Ancak daha sonraki dönemlerde kazandığ 1 anlama işaret eden rivayetler bulunmaktadır. En baştan beri müridin şeyhini sevmesi, onun emrinden dışarı çıkmaması hatta kendi ile tevessül edilmesini istemekle ilgili çeşitli rivayetler gelmiştir.

Mesela, Ma'rûf el-Kerhî̀nin (ö. 200/816) yeğenine, “Ey oğulcuğum, Allah'tan isteyeceğin bir ihtiyacın olduğu zaman, onu beni aracı kılarak iste" ${ }^{\text {"11 }}$ dediği nakledilmiştir. Necmüddin-i Kübrâ’nın (öl. 618/1221) naklettiği Cüneyd-i Bağdâdî’nin (ö. 297/909) sekiz şartından biri olan "devamlı olarak şeyhe kalbi raptetmek ve kendi tasarrufunu şeyhin tasarrufunda yok ederek ilm-i vâklât konusunda ondan istifâde etmek" ifadesi, ${ }^{12}$ Abdülkādir-i Geylânî’den (ö. 561/1165-66) nakledilen râbıtaya işaret eden bazı ifadeler, ${ }^{13}$ şeyhin sûretini değil ama sîretini düşünme mânâsına râbitanın adı konulmadan tavsiye edildiğini göstermektedir.

Şehâbeddin Sühreverdînnin (ö. 632/1234), "Müridin şeyhine nazar ederek bütün dikkatini onda toplaması ve Cenâb-1 Hak'tan şeyhi üzerine gelen tecellîleri seyre dalması semâ‘da kendi kendine hareket etmesinden daha hayırlıdır”14 demesi, doğrudan sûrete bakılarak yapılan râbıtaya işaret etmektedir.

11. Ahmed b. Abdillâh Ebû Nuaym el-İsfahânî, Hilyetü 'l-evliyâ' ve țabakātü 'l-așfiyâ (Beyrut: Dâru'l-Kütübü'l-İlmiyye, 1988), 8/364.

12. Ebü'l-Cennâb Necmeddîn-i Kübrâ, Fevẩihu'l-cemâl ve fevâtihu'l-celâl, thk. Yusuf Zeydan (Kahire: Dâru Suâd es-Sabâh, 1993), 124; Zeynüddin Hâfî̀nin kitabında bu madde, "müridin inanarak ve manen yardımını umarak tam bir teslimiyet, muhabbet ve işlerinde hakem kılarak kalbini şeyhe bağlamaya devam etmesidir." şeklindedir. bk. Zeynüddin Hâfî, el-Veșâya’l-Kudsiyye (Dâru'l-Kütübü'l-Katariyye, 1065), 107-108b; Köle, Zeynüddin Hâfî, 144-145, 217-218; Bu sekiz şart için bir makale yazan Süleyman Gökbulut'un tesbitine göre daha sonraki Kübrevî şeyhleri bu sekiz şartı yazmış ve çoğunluğu râbıta ile ilişkili maddeyi de dahil edip açıklamalar yapmıştır. bk. Süleyman Gökbulut, "Cüneyd'in Sekiz Şartı", Dokuz Eylül Üniversitesi İlahiyat Fakültesi Dergisi 2/36 (2012), 201-231. Yaptığımız araştırmada Cüneyd-i Bağdâdî’ye atfedilen sekiz şartı, özellikle de râbıta ile ilgili şartı Cüneyd'den bahseden hicri VI. yüzyıldan önce yazılan eserlerde bulamadık. Gökbulut, bunların Cüneyd'in farklı zamanlarda dile getirdiği tasavvufî ilkelerin bir araya getirilmiş hali olduğu kanaatindedir. bk. Gökbulut "Cüneyd'in Sekiz Şartı", 227. 13. Abdülkādir Geylânî (ö. 561/1165-66) bir şiirinde müritlerinden kendisiyle tevessül edilmesini istemiştir. Şiir için bk. Muhyiddîn Ebû Muhammed Abdülkādir Geylânî, Fütûhu’l-ġayb (Kahire: y.y., 1973), 237. Dilaver Selvi, Tasavvuf Metodu Olarak Rabita (İstanbul: Semerkand Yayıncilık, 2016), 103.

14. Ebû Hafs Şihâbüddîn Ömer es-Sühreverdî, Avârifu'l-Meârif (Kahire: Dâru'l-Meârif, ts.), 2/214; Ebû Hafs Şihâbüddîn Ömer es-Sühreverdî, Avarifü'l-Meârif: Gerçek Tasavvuf, çev. 
Şeyhin gıyabında sûretini düşünmek şeklinde yapılan râbıtanın ilk olarak Bahâeddin Nakşibend (ö. 791/1389) tarafından seçkin müridi Muhammed Parsầya (öl. 822/1420) telkin edildiği ${ }^{15}$ ifade edilmiştir. Ancak Desûkıyye tarikatının kurucusu İbrahim Desûkî’den (ö. 676-1277) "mürit doğuda, kendisi batıda da olsa kendisinin karaltısını görebilecekleri, bir sıkıntıları olur, Allah'tan soracakları bir şey olursa, gözlerini kapatıp kalp gözlerini açarlarsa kendisini açıkça görüp işlerini istişare edebilecekleri”"16 ifadesi nakledilmiştir. Ayrıca Şazelî şeyhi İbn Atâullah el-İskenderî (ö. 709/1309) zikrin âdâbını anlatırken: "Dediler ki: Zikir yapan kişi, bir şeyhin gözetimi altında (bir şeyhe bağlı) ise, zikir yaparken şeyhinin hayâlini gözü önüne getirmelidir, çünkü şeyh, onun bu yoldaki refiki (yoldaşı) ve rehberidir. Zikre başlarken, şeyhinin istimdadının Rasûlullah'tan olduğuna inanarak, şeyhin himmetinden istimdad eder. Çünkü şeyhi Rasûlullah'ın nâibidir."17 demektedir. Bu sözler, şeyhin sûretini düşünmek şeklinde bir râbıtanın Bahâeddin Nakşibend'den çok daha önce Mısır'da başladığına işaret etmektedir.

Râbıta ile ilgili ilk detaylı bilgiye Ubeydullah Ahrâr'da (ö. 895/1490) rastlandığı, onun, râbıtada şeyhin iki kaşının arasına yönelmek gerektiğini söylediğ ${ }^{18}$ ifade edilmiştir. Ancak gerek İbn Atâullah'tan yapılan üstteki aktarma, gerekse Zeynüddin Hâfî̀nin (ö. 838/1435), Cüneyd-i Bağdâdî’den halvetin sekiz şartını aktarırken ikinci şartta yaptığı açıklamada, "şeyhinin hayalini göz önüne getirir, çünkü şeyh onun bu yolda refikidir (yoldaşıdır). Ĕger şeyh hakiki bir şeyh ise ruhaniyeti her müridine refik olur (yoldaşlık yapar)" ifadesi ${ }^{19}$ Şazelîyye tarikatında ve Sühreverdiyye’nin en azından Zeyniyye kolunda zikir esnasında şeyhe nasıl râbıta yapılacağı hakkında bilgi verildiğini göstermektedir.

Dilaver Selvi (İstanbul: Semerkand Yayınları, 2010), 531.

15. Necdet Tosun, Bahaeddin Nakşbend: Hayatı, Görüşleri, Tarikatı (İstanbul: İnsan Yayınları, 2015), 315; Gündüz, “Tasavvufî Bir Terim Olarak Râbıta”, 29-30.

16. Hasan Hilmi, es-Sifrü’l-esnâ, 78.

17. İbn Atâullah el-İskenderî, Miftâhu'l-felâh ve miṣbâhu'l-ervâh (Mısır: Matbaatü's-Saâde, ts.), 17.

18. Tosun, Bahaeddin Nakşbend, 316.

19. Zeynüddin Hâfî, el-Veșâya'l-Kudsiyye (Dâru'l-Kütübü'l-Katariyye, 1065), 105b; Köle, Zeynüddîn Hâfi, 141, 214; Hasan Hilmi, es-Sifrül-esnâ, 86. 
Râbıta, Nakşibendiyeye has bir uygulama gibi gözükse de Halvetiyye, Kādiriyye ve Çiştiyye, ${ }^{20}$ Rifâiyye, Şazeliyye, Şa râniyye ${ }^{21}$ gibi çok sayıda tarikatta râbıtanın bulunduğu ifade edilmektedir.

Birçok tarikattan icazetli olan ${ }^{22}$ Abdülvehhab Şa ‘rânînnin (ö. 973/1565), zikrin âdâbını anlattığı bölümde, zikre başlarken dikkat edilmesi gereken edeplerden dördüncüsü olarak, müridin şeyhini iki kaşı arasında düşünerek şeyhinden himmet istemesini; zikir esnasındaki yedinci edeb olarak da, sâlikin zikre devam ettiği müddetçe şeyhinin sûretini iki gözü ortasında hayâl ve tasavvur etmesi olarak sayıp ardından "Bu iş (râbıta), şeyhlere göre edeplerin en gereklilerindendir. Çünkü bu sayede mürit, Allah Teâlâ ile beraber olma edebine ve O'nu murâkabe hâline ulaşır"23 ifadesi neredeyse tarikatların tamamına yayılan bir râbıta anlayışı olduğunu göstermektedir.

Bununla birlikte râbıta hakkındaki müstakil risale ve eserlerin tamamına yakını Nakşibendî şeyhleri veya müritleri tarafından yazılmıştır. Tespit edilebildiği kadarıyla râbıta konusunda müstakil olarak kaleme alınan ilk eser Hâlid-i Bağdâdî̀ye (ö. 1242/1826) ait olan İstanbul'daki bir halifesine gönderdiği risaledir. ${ }^{24}$ Râbıtayı savunmak üzere kaleme alınan bu risale Nakşîbendîler tarafından çoğaltılmış ve daha sonra bu konuda yazılan tüm eserlere kaynaklık etmiştir.

Râbıta hakkındaki bilgilere bakıldığında râbıtanın ilk başlarda tüm müritlere değil seçkin müritlere tavsiye edildiği anlaşılmaktadır. ${ }^{25}$ Ancak daha sonra râbita mübtedî müritlere verilen bir ders, onlardan istenen bir eğitim metodu haline gelmiştir. Murakabe dersine gelen, ${ }^{26}$ seyr u sülûkte ilerlemiş müridin mürşit râbıtasını bırakacağı 1 ifade edilmiştir. ${ }^{27}$

20. Tosun, "Râbita”, 34/378.

21. Kadir Taşpınar, Tasavvufta Mürşid Rabıtası (Rize: Recep Tayyip Erdoğan Üniversitesi, Sosyal Bilimler Enstitüsü, Yüksek Lisans Tezi, 2010), 96-97.

22. Hayri Kaplan, "Şa 'rânî”, Türkiye Diyanet Vakfi İslâm Ansiklopedisi (İstanbul: TDV Yayınları, 2010), 38/347. Şa'rânî’nin yirmi altı tarikattan icazetli olduğu ifade edilmektedir.

23. Ebü'l-Mevâhib Abdülvehhâb eş-Şa'rânî, el-Envârü’l-ḳudsiyye fî beyâni kavấ'idi'ṣ-ṣ̂ufiyye, thk. Taha Abdulbâki Surûr - Muhammed Abduşşâfî' (Beyrut: Mektebetü’l-Meârif, 1988), 36-37.

24. Bu risale yazma eser kütüphanelerine genellikle "Risâle fî̀r-Râbıta" veya "Risâletü’r-Râbıta" isimleriyle kaydedilmiştir.

25. Tosun, Bahaeddin Nakşbend, 315-316.

26. Cebecioğlu, Tasavvuf Terimleri ve Deyimleri Sözlüğü, 507.

27. Hasan Hilmi, es-Sifrül-esnâ, 75-76; Abdulhakim Yüce, "Mevlanâ Halid Bağdadî’ye Göre Şeyh-Mürid İlişkisi ve Rabıta”, Uluslararası Mevlana Halid-i Bă̆dadi Sempozyumu Bildirileri, 
Muhammed Hânî (ö. 1318/1900), müridin doğrudan Allah Teâlâ’dan feyz alma kabiliyetine gelene kadar râbıtayı terk etmemesi gerektiğini, o hale gelince de şeyhini sevmeye devam etmesi ancak râbıtayı terk etmesi gerektiğini söylemektedir. ${ }^{28}$ Ancak müridin bu makama geldiğini kimin tayin edeceği hakkında bir açıklama yoktur. Herhalde mürit halini şeyhe aktaracak o da mürşit râbıtasını bırakmasını veya devam etmesini isteyecektir.

\subsection{Râbıtanın Çeşitleri}

Râbıta ile ilgili eser kaleme alanların beyanına göre râbıtanın ilk türü muhabbet râbıtasıdır. Konuyla ilgili eser kaleme alanlardan bazılarının belirttiğine göre muhabbetten kaynaklanan kalbî râbıta, sahabe, tâbiin ve tebe-i tâbiin hazerâtında zorlanmaksızın kendiliğinden meydana geliyor, ayrıca onlara uyarıcı bir ikazda bulunulmuyordu. Zamanla toplum bozulduğu, kişilerin kalpleri gereksiz şeylerle meşgul olup bu sevgi azaldığ için, tarikat ehli bunun yerine müritlerin kalplerini Cenâb-1 Hakk'a bağlamak maksadıyla kâmil şeyhlere râbıtayı bir usûl olarak benimsemişler ${ }^{29}$ ve farklı şekillerde râbıta yapılması istenmiştir.

Râbıtanın yapılış şeklini ilk târif edenlerden Tâcüddin b. Zekeriya'ya göre, râbitada şeyhin sûreti sağ omuzda düşünülür ve buradan kalbe uzanan bir durum (ruhânî bir kuvvet) farz edilir. Şeyh buradan kalbe yürüyerek gelir. ${ }^{30}$

Hâlid-i Bağdâdî’ye göre ise râbıtanın en güzel yapılış şekli şöyledir: Mürit iki gözünün arasında bulunan hayal hazinesi ile mürşidinin, feyz kaynağı olan iki gözünün arasına bakar. Tazarru ederek ve tevessül niyetiyle şeyhinin hayalinin iki gözünün arasındaki hayal hazinesine dahil olduğunu, oradan kalbine ve kalbinin derinliklerine indiğini, kendisinin de onunla beraber indiğini hayal eder. Kendisini unutsa bile şeyhini unutmaz. ${ }^{31}$

Muhammed Hânî altı çeşit râbıta saymaktadır: 1. Müridin kâmil şeyhinin sûretini iki gözü arasında düşünüp ruhaniyetine teveccüh etmesi

ed. Erdal Baykan - Mehmet Keskin (Ankara: Yüzüncü Yıl Üniversitesi İlahiyat Fakültesi - Van İl Müftülüğü, 2012), 88; Gündüz, “Tasavvufî Bir Terim Olarak Râbıta”, 34.

28. Hânî, el-Behcetü's-seniyye, 74; Hânî, Âdâb, 223.

29. Dağıstânî, Fetvalar, 152; Taşpınar, Tasavvufta Mürşid Rabıtası, 57.

30. Nablusî, Miftâhu'l-ma'iyye, 94.

31. Hâlid el-Bağdâdî, Halidiyye Risalesi, çev. A. Suat Demirtaş (İstanbul: Semerkand Yayınları, 2010), 50. 
(yönelmesi). 2. Şeyhinin sûretini iki yanında tasavvur ve kendisinde gaybet hali ve cezbe eseri ortaya çıkana kadar ruhaniyetine teveccüh etmesi. Bu iki râbıta çeşidinde gaybet ve cezbe hallerinden biri olursa mürit râbıtayı bırakır, onlara yönelir; bu haller geçince tekrar râbıta yapar. 3. Şeyhin sûretini müridin alnında tahayyül etmesi. Bu râbıtada mürit, şeyhini alnının ortasına oturtur. 4. Müridin, şeyhin sûretini kalbinin ortasında hazır etmesidir. 5. Müridin, şeyhin sûretini alnında tasavvur edip oradan kalbinin ortasına indirmesidir. Mürit, kalbini geniş bir dehliz gibi düşünür ve tüm havâtırı keser. 6. Müridin, nefsini nefyetmesi (ortadan kaldırması) şeyhini sabit bırakmasıdır. Yani müridin, kendi yerinde şeyhi olduğunu düşünmesidir. ${ }^{32}$

Nu’manoğlu Kâtip Mustafa Fevzi (ö. 1924), râbıtanın yapılışını şöyle târif etmiştir: Göz yumulur, kalbi kalbine gelecek şekilde şeyhi tam karşısında oturuyor şekilde, kendi kalbi küçük bir havuz, şeyhin kalbi bir deniz şeklinde; Rasûlullah'tan gelen feyz ve nur şeyhinden kendisine akıyor diye düşünülür. ${ }^{33}$

Bunun haricinde müridin kendisini şeyhinin heyet ve kıyafetindeymiş gibi tahayyül etmesi, ${ }^{34}$ mürşidin vücuduyla müridin vücuduna girmesi, müridin kendisinin mürşidin vücudunda yok olup bir olduklarını düşünmesi şeklinde râbıta çeşitleri de sayılmış ve bunlar için şeklî râbıta veya suverî râbıta adı verilmiştir. ${ }^{35}$

Râbıtanın yapılış şekilleri yanında bir de yapılma zamanları ve yerleri de vardır. Buna göre:

1. Huzur râbıtası: Şeyhin huzurunda iken kendisine yapılan râbıtadır. Mürit şeyhi tahtına oturmuş bir sultan, kendisini de ondan bir şey bekleyen fakir biri gibi düşünüp gönülden yardım talebinde bulunur. ${ }^{36}$

2. Mânevî râbıta: Hayalî râbıta da denilen bu râbıta her zaman yapılabilir. Müridin gündelik işlerinde bile mürşidi yanında düşünmesidir. Özellikle uyumadan önce ve günahla karşı karşıya geldiğinde râbıta

32. Hânî, el-Behcetü's-seniyye, 72-73. Bu bölümün Türkçe tercümesi Âdab'da bulunmamaktadır. 33. Mustafa Fevzi, Kitab-ı isbâtü'l-mesâlik fi râbitati's-sâlik (İstanbul: y.y., 1324/1906), 47. 34. Abdülhakim Arvâsî, Râbıta-i Şerife (İstanbul: y.y., 1976), 8-9, 19. 35. Selvi, Rabıta, 171-172; Yahya el-Abbas el-Hâşimî Pakiş, Râbıta Risâlesi, çev. Süleyman Taş (İstanbul: Buhara Vakf1, 1997), 62-63. 
yapılması tavsiye edilmiştir. ${ }^{37}$ Namaza başlarken ve bitirdikten sonra râbıta yapılması tavsiye edilmiş ancak namazda iken râbıta yapılmaması söylenmiştir. ${ }^{38}$

3. Özel ders râbıtası: Nakşîlerde müridin akşam yatsı arası bir vird gibi yaptığı râbıtadır. Bu râbıtada mürit, şeyhin yüzünü gözünün önüne getirir, şeyhinin yüzünün dolunay gibi parladığını, nur şeklinde feyzlerin ondan gelip, kendi kalbine aktığını ve o nurun bütün vücuduna yayıldığını düşünür. On-on beş dakika sürer. ${ }^{39}$

4. Zikirde râbıta: Müridin kendisine verilen günlük vird esnasında yaptığı râbıtadır. Buna istimdat râbıtası denir. Bu râbıta kalbi zikre hazırlamak, mânevî uyanıklığı temin etmek için yapılır. Şeklî râbıtaya benzer. ${ }^{40}$ Râbıta ile ilgili târifler ve zikir âdabını anlatan eserlere nazaran, şeyhin sûretini göz önüne getirip ondan feyz geldiğini düşünmek mânâsındaki râbıtanın zikir esnasında da yapılacağı akla gelmektedir. Ancak bununla ilgili Nakşî kaynaklarının bir bölümü bu çeşit râbıtanın zikre başlamadan önce yapılacağını, zikir esnasında bu tür bir râbıtanın yapılamayacağını ancak şeyh yanında imiş gibi râbıta yapılacağını ifade etmişlerdir. ${ }^{41}$

5. Sohbet ve hatmede râbıta: Mürşidin sohbetinde doğrudan kendine bakarak, başkasının yaptı̆̆ı sohbette sanki mürşidi sohbeti yapıyormuş gibi düşünerek, hatmede de yine mürşidinin huzurunda olduğunu düşünerek yapılan râbıtadır. ${ }^{42}$

6. Kabir ziyaretlerinde râbıta: Vefat etmiş bir velîyi ziyaret eden müridin kalbiyle kabirdeki zata yönelip feyz beklemesidir. ${ }^{43}$ Bu râbıtanın yapılışş şekli şöyledir: Kabirdekine selâm verilir, sağ ayağı yakınına oturulur, râbıta yapan göbeği üzerinde sağ elini sol eli üzerine koyar, başını göğsüne eğer, bir Fatiha, on bir İhlas ve bir Âyete'l-Kürsî okuyarak o zatın ruhuna hediye eder. Sonra orada oturup feyz almak için o kişinin ruhaniyetine teveccüh eder. ${ }^{44}$ Bu târif Hâlid-i Bağdâdî̀ye göredir. ${ }^{45}$ Kuşadalı

37. Selvi, Rabıta, 172-175; Pakiş, Râbıta Risâlesi, 65-66.

38. Selvi, Rabıta, 173; Mustafa Fevzi, İsbâtü'l-mesâlik, 26.

39. Selvi, Rabıta, 181-182; Pakiş, Râbıta Risâlesi, 63.

40. Selvi, Rabita, 182-183.

41. Mustafa Fevzi, İsbâtü'l-mesâlik, 26.

42. Selvi, Rabıta, 183-187; Pakiş, Râbıta Risâlesi, 62.

43. Selvi, Rabıta, 187-189.

44. Hânî, el-Behcetü's-seniyye, 73-74; Hânî, Âdâb, 221.

45. Taşpınar, Tasavvufta Mürşid Rabıtası, 100. 
İbrahim Halvetî (ö.1262/1846) ise ölmüş kimselere râbıta yapılmasını faydasız bulmuş ve müritlerine yasaklamıştır. Ona göre râbıta yapanların şeyhin bizzat simasını görmeleri, âmâ olanların ise sesini duymuş olmaları gerekmektedir. Şeyhin sûretini târif ile bile râbıtayı kabul etmemiştir. ${ }^{46}$

Burada şunu belirtmek gerekir ki sayılan bu çeşitlerin tamamı Nakşîbendiyye'nin tüm kollarında uygulanmamaktadır. Hepsinde râbıta bulunmasına rağmen çeşitlerinin uygulanması koldan kola farklılık arz edebilmektedir. Mesela son devrin Nakşî şeyhlerinden Mahmud Sami Ramazanoğlu'na göre râbıtanın esası muhabbettir ve râbıtada mürşidin hayalini tefekkür etme gereği yoktur. ${ }^{47}$ Ona göre muhabbetin gereği muvâfakattir. Şeyhini seven ona muvâfakat eder ve onun istediği amelleri işler. Bu da in'ikâs yoluyla mürşidin halinin müritte gerçekleşmesine yol açar. ${ }^{48}$

Râbıta ile ilgili ilk yazılan eserlerde kadın müritlerle ilgili bir açıklama olmamasına rağmen Dilaver Selvi, kadınların şeyhin şeklini düşünmeden, şeyhini bir nur şeklinde tasavvur ederek râbıta yapacağını söylemektedir. ${ }^{49}$ Ancak şifahî olarak edindiğimiz bilgiye göre uygulama erkeklerle çok farklı değildir.

Râbita yapılacak kişinin özellikleri üzerinde de durulmuştur. Muhammed Hânî, râbıtanın ancak velâyet kudretiyle tasarrufta bulunabilen insân-1 kâmile yapılabileceğini söylemiş, ${ }^{50}$ bu mürşid-i kâmili, fenâfillah makamını geçmiş bekābillah makamında bulunan kişi olarak tanımlamıştır. ${ }^{51}$ Bu ifadeleri farklı şekilde tekrarlayan Arvâsî, kendisine râbıta yapılması$\mathrm{n} ı$ isteyen birinin buna liyakatini ancak böyle yüksek derecelere ulaşmış şeyhinin veya Allah ricalinin şehadet etmesi gerektiğini, layık olmayanlara râbıta yapmanın yapana zarar verdiği gibi yaptırana daha büyük zarar vereceğini söylemektedir. ${ }^{52}$ Bununla birlikte uygulamada, tarikatlarda böyle bir mekanizma bulunmamakta, şeyh olarak kim kabul edilmişse ona ve onun bağlı olduğu silsiledeki kişilere râbıta yapılmaktadır.

46. Gündüz, "Tasavvufî Bir Terim Olarak Râbıta”, 42; Betül İzmirli, "Kuşadalı İbrâhim Halvetînnin Râbıta Hakkındaki Görüşleri”, Akademik İslâm Araştırmaları Dergisi 7 (Aralık 2019), 110.

47. Mahmud Sâmi Ramazanoğlu, Musâhebe (İstanbul: Erkam Yayınları, 1983), 6/151.

48. Ramazanoğlu, Musâhebe, 6/154.

49. Selvi, Rabita, 250-251.

50. Hânî, el-Behcetü's-seniyye, 73; Hânî, Âdâb, 221.

51. Hânî, el-Behcetü's-seniyye, 74-75.

52. Arvâsî, Râbıta-i Şerife, 24-27; Selvi, Rabıta, 161-162. 


\section{Râbitayı Savunanların Delilleri}

19. yüzyıla kadar râbıta hakkında önemli bir eleştiri yapılmamıştır. 19. ve 20. yüzyıllarda Hindistan'da kendisi de bir Nakşibendî Müceddidî olan Ahmed Şehîd Birîlvî (öl. 1246/1831) ile Sıddîk Hasan Han Kannevcî (ö. 1307/1890) ve İstanbul'da Hâfız Seyyid Hoca başta olmak üzere bazı kişiler tarafından râbıtaya eleştiriler yöneltilmiştir. Eleştirenlerin çoğu râbıtayı sadece bidat olarak görürken, Hâfız Seyyid Hoca onun hem bidat hem şirk olduğunu ve putperestlik âdetlerine benzediğini öne sürmüştür. Bu eleştiriler üzerine bilhassa Nakşibendî Hâlidî mensupları râbıtayı savunmak için eserler kaleme almışlardır. ${ }^{53}$

19. yüzyılda râbıtayı savunmak üzere kaleme alınan eserlerde ilim geleneği üzere âyetlerden, hadislerden, icmâ ve kıyastan deliller ile dört mezhep âlimlerinin sözlerinden delil getirilmiştir. Özellikle 1980'li yıllardan sonra Türkiye'de yapılan akademik çalışmalarda bunlara insan psikolojinden deliller de eklenmiştir. İcmâ delili olarak tasavvuf ehlinin icmâı gösterildiği için ${ }^{54}$ burada onunla ilgili bir şey zikredilmeyecek, diğer deliller üzerinde durulacaktır.

\subsection{Râbıtayı Savunmak İçin Delil Getirilen Âyetler}

Râbıtayı savunanlar bu hususta çok sayıda âyet delil getirmişlerdir. Bunların bir kısmı şunlardır:

1. "Ey îmân edenler! Allah'tan korkun. Bir de sâdiklarla beraber olun!"55 âyetinde geçen 'sâdıklarla beraberlik' râbıtaya delil olarak ileri sürülmüştür. Hâce Ubeydullah Ahrâr’a (ö. 895/1490) göre bu âyet sâdıklarla hem sûreten hem de mânâ ile birlikte olmayı emretmektedir. Sâdıklarla mânen birlikte olmanın adı da râbıtadır. ${ }^{56}$ Âyette asıl kast olunan kalbî

\footnotetext{
53. Tosun, "Râbita”, 34/378.

54. bk. Hüseyin ed-Devserî, er-Rahmetü’l-hâhbita fi tahkîk'ir-râbița (İstanbul: y.y., ts.), 1/538; Hasan Hilmi, es-Sifrüll-esnâ, 74-75.

55. Hayrettin Karaman vd. Kur'ân-ı Kerim ve Açıklamalı Meali (Ankara: Türkiye Diyanet Vakfı Yayınları, 1993), et-Tevbe 9/119.

56. Mevlâna Ali b. Hüseyin Safiyyüddin, Reşahat Ayn el Hayat: Can Damlaları, sad. Necip Fazıl Kısakürek (İstanbul: Eser Kitabevi, 1978), 273-274; Hâlid el-Bağdâdî, Risâle fî̀ r-Râbıta, (Yazmalar Koleksiyonu, 6129/9), 53b; Hâlid el-Bağdâdî, er-Risâletül-Hâlidiyye, 25.
} 
beraberliktir. Zâhiren biriyle beraber olup da kalben beraber olmayan ondan istifade edemez. ${ }^{57}$

Hasan Hilmi Efendi, "Sâdıklarla beraber olunuz!” âyeti için Ubeydullah Ahrar'ın yaptığı tefsirin çok güzel olduğunu, bu âyete göre savaşlarda ve diğer amellerde sâlihlerle beraber olma emredildiğini, müridin de en büyük put olan nefs-i emmâre ile büyük bir savaşta olup bunu şeyhiyle beraber yürüttüğünü, bu savaşın ancak şeyhini hayal etmek ve ona tâbi olmakla mümkün olduğunu, bunun da râbita olduğunu söylemektedir. ${ }^{58}$

2. "Ey îmân edenler! Allah'tan korkun ve O'na yaklaşmaya vesile arayın ve O’nun yolunda savaşın! Ta ki muradınıza eresiniz!"59 Bu âyette geçen 'vesile'nin umûmî olduğu ve râbıtanın bu vesilelerden biri olarak kabul edilmesi gerektiği ileri sürülmüştür. ${ }^{60}$ Sâlihlerle tevessülü kabul edenler mutlak anlamda vesîlenin hem şahıslara, hem de amellere şâmil olacağını söylemiş ve bunu sünnetin Kur'ân-ı Kerim’i tefsir fonksiyonundan istifade ederek, Hz. Peygamber ve ashâbının uygulamasıyla delillendirmişler, 'âyetteki mutlak ifadeyi sınırlamanın ancak bir delille mümkün olabileceğini, Kur'ân'da ise böyle bir kaydın bulunmadığını' iddia ederek râbıtayı vesilelerden biri saymışlardır. ${ }^{61}$

Bu âyeti râbıtaya delil getirenlerden Hüseyin ed-Devserî şöyle bir akıl yürütmesi yapmıştır. Vesile sâlih amellerdir. Bir amel ancak ihlas ile sâlih olur. Bir amelin hâlis olması için şâibelerden uzak olması gerekir. Bizim tecrübemize göre râbita ile meşgul olduğumuzda amellerimiz gaflet şâibesinden uzak kalmaktadır. Gaflet içinde yapılan amelden sevap elde edilmemektedir. Gafletten uzak kalmak maksut olduğuna, râbita da bu maksudu sağladığına göre, en güzel vesilelerden olmaktadır. ${ }^{62}$

3. "De ki ĕger siz, Allah'ı seviyorsanı, hemen bana uyun ki Allah da sizi sevsin ve suçlarınız mağfiretle örtsün. Allah gafûrdur, rahîmdir." ${ }^{33}$ Râbıtayı savunanlar, bu âyette geçen 'ittibâ' in gerçekleşebilmesi için ya hissen ya

57. Mustafa Fevzi, İsbâtü’l-mesâlik, 29-30.

58. Hasan Hilmi, es-Sifrü'l-esnâ, 46.

59. el-Mâide 5/35.

60. Arvâsî, Râbıta-i Şerife, 8, 28; Mustafa Fevzi, İsbâtü’l-mesâlik, 28.

61. Gündüz, "Tasavvufî Bir Terim Olarak Râbıta”, 43.

62. Devserî, er-Raḥmetü’l-hâbita, 1/537-538.

63. Âl-i İmrân 3/31. 
da hayalen tâbi olunanın görülmesinin gerekli olduğunu râbıtanın hayalen görme olduğunu söylemişlerdir. ${ }^{64}$

4. "Andolsun Allah'ın Rasûlünde sizin için, Allah'ı ve âhireti arzu eden ve Allah’ı çok anan kimseler için, (uyulacak) en güzel bir örnek (üsve-i hasene) vardır." "İbrahim'de ve onunla birlikte bulunanlarda sizin için güzel bir misal var."66 âyetlerinde geçen üsve kelimesi de râbitaya delil olarak gösterilmiştir. ${ }^{67}$

5. "Kadin cidden ona niyeti kurmuştu, ĕger Rabbinin burhanın görmese idi o da ona kurmuş gitmişti. Ondan fenâlı̆̆ı ve fuhşu uzaklaştırmak için öyle oldu. Hakikat o bizim ihlâsa mazhar edilmiş has kullarımızdandır."68 Sûfîler, bu âyetteki burhanı Zemahşerî̀nin (ö. 538/1144) ${ }^{69}$ de içinde olduğu müfessirlerin çoğunluğunun Hz. Yâ'kūb'un (a.s.) o anda Hz. Yûsuf'a (a.s.) görünerek onu uyarması olarak tefsir ettiklerini ${ }^{70}$ söyleyerek âyeti, kâmil velîlerin uzaktan imdat ve tasarrufuna delil kabul etmiş; ${ }^{71}$ buradan da râbıtaya delil çıkarmışlardır. ${ }^{72}$

6. "Muhakkak Allah ve melekleri Nebî'ye çok salât ederler. Ey îmân edenler siz de Ona salât edin ve tam bir teslimiyetle selâm verin!"73 âyetini râbıtaya delil getiren Hasan Hilmi Efendi, râbıtanın aslının Rasûlullah'a olduğunu, doğrudan Rasûlullah'a ancak ehlinin râbita yapabileceğini söylemektedir. ${ }^{74} \mathrm{~Hz}$. Peygamberin adı anıldığında salât ü selâm getirmek bunu yapan ile Rasûlullah arasında bir sevgi ve saygı bağı oluşturacak,

64. Arvâsî, Râbıta-i Şerife, 29; Gündüz, “Tasavvufî Bir Terim Olarak Râbıta”, 45; Hasan Hilmi, es-Sifrü'l-esnâ, 115.

65. el-Ahzâb 33/21.

66. el-Mümtehine 60/4.

67. Gündüz, “Tasavvufî Bir Terim Olarak Râbita”, 49.

68. Yûsuf 12/24.

69. Ebü'l-Kāsım Mahmûd b. Ömer ez-Zemahşerî, el-Keşşâf'an hakā’iḳı gavâmiżi’t-tenzîl ve 'uyûni’l-ekāvîl fî̀ vücûhi't-te'vîl (Beyrut: Dâru'l-Kitâbi'l-Arabî, 1407), 2/458. Zemahşerî bu görüşü "qîle/denildi” diyerek aktarmış ve sonunda "bu ve benzeri rivayetler haşv ve cebr ehlinin sözleridir” demiştir.

70. Ebû Ca'fer et-Taberî, Câmi'u'l-beyân 'an te'vîli âyi'l-Ḳur'ân, thk. Ahmed Muhammed Şâkir (Beyrut: Müessesetü’r-Risâle, 2000), 16/34, 40-47; Ebû Zekeriyyâ Yahyâ b. Ziyâd el-Ferrâ, Meâni'l-Kur'ân, thk. Ahmed Yûsuf Necâtî vd. (Kahire: Dâru'l-Mısriyye, 1955), 2/40; Ebû İshak İbrahim ez-Zeccâc, Me'âni'l-Kur'ân ve i'râbüh, thk. Abdülcelîl Şelebî (Beyrut: Âlemü>l-Kütüb, 1988), 3/101.

71. Taşpınar, Tasavvufta Mürşid Rabıtası, 33.

72. Hâlid el-Bağdâdî, Risâle fî̀r-Râbıta (Yazmalar Koleksiyonu, 6129/9), 54a; Arvâsî, Râbıta-i Şerife, 32.

73. el-Ahzâb 33/56.

74. Hasan Hilmi, es-Sifrü’l-esnâ, 68. 
böylece bu kişinin Hz. Peygamber'e olan sevgisi artacaktır. Bu da bir tür râbita olarak değerlendirilebilir. ${ }^{75}$

Mehmed Fevzi Efendi (ö. 1900), bu âyetler haricinde, "Rükû edenlerle beraber rükû edin" ve "Kim Allah'a ve Rasûl'e itaat ederse işte onlar, Allah'in kendilerine lütuflarda bulunduğu peygamberler, siddîkler, şehidler ve sâlih kişilerle beraberdir. Bunlar ne güzel arkadaştır!"’7 âyetlerini de zikrederek, bu âyetlerin bâtın ehli tarafından râbitaya delil olarak görüldügünü, zâhir müçtehitlerin kendi alanında delil kabul edildiği gibi bâtın müçtehitlerinin de kendi alanlarında delil alınması gerektiğini iddia etmektedir. ${ }^{78}$

\subsection{Râbıtayı Savunmak İçin Delil Getirilen Hadisler}

Râbıtayı savunmak için delil getirilen hadislerin bir kısmı ${ }^{79}$ şunlardır:

1. "Ameller niyetlere göredir. Kişiye ancak niyet ettiğinin karşllı̆̆ vardır." ${ }^{\prime 0}$ Râbıtaya bu hadisi delil getiren Hüseyin ed-Devserî̀ye göre, mubah bir hareket ve tasavvur, kişi bununla istediğine ulaşamasa bile, niyet ile taat ve takva oluyorsa, niyetiyle muradına ulaştı̆̆ında evleviyetle olur. ${ }^{81}$

2. "Ben sizden birine, kendisinden, anne-babasından, evlatlarından ve insanların tamamından daha sevimli olmadıkça, îmânda kemâle eremezsiniz." 82

Bu hadisteki emir şu anda ancak Rasûlullah'a kalbini bağlayarak yani bir çeşit râbıta ile gerçekleştirilebilir. Bu hadisin râbıtaya işaret ettiğini

75. Dağıstânî, Fetvalar, 165.

76. el-Bakara $2 / 43$.

77. en-Nisâ 4/69.

78. Edirne Müftüsü Mehmed Fevzi Efendi, 'Aynüll-ḥakîka fî râbitatì't-tarîka (b.y.: y.y., ts.), 2021. Edirne Müftüsü Mehmed Fevzi Efendi, Filibe Şerafeddin Paşa Medresesinde müderris ve aynı zamanda Nakşî şeyhi olan üstadına yaptığı bir ziyarette, râbıtaya put, râbıta yapana da putperest diyen bir risale gördüğünü, buna cevap olarak bu risaleyi yazdığını söylemektedir. bkz. Fevzi Efendi, 'Aynül'-ḥakîka, 2-3. Gördüğü risale Hâfız Seyyid Hoca'ya ait risale olmalıdır. Çünkü aktardığı cümleler ona aittir. Risale'de iddialar parça parça alınmış ve cevap verilmiştir. 79. Râbıtayı savunmak üzere kaleme alınan ilk eserlerde hadis sayısı fazla yok iken daha sonra yazılanlarda hadisler epeyce artırılmıştır. Bu hususta en geniş yazanlardan Dilaver Selvi, râbıta için çok sayıda hadisi delil olarak getirmiştir. Ancak bunların çoğunun delil olma yönü çok uzaktır. 80. Müslim b. el-Haccâc, el-Câmi'u'ş-șahîh, nşr. Muhammed Fuâd Abdülbâkī (Kahire: y.y., 137475/1955-56), "İmâre", 155; Ebû Abdillâh Muhammed b. İsmail el-Buhârî, el-Câmi'u'ș-ṣahîhh, nşr. Muhammed Züheyr b. Nasr (b.y.: Dâru Tavki’n-Necât, 1422/2001), "Bed'ül-Vahy”, 1.

81. Devserî, er-Rahmetü'l-hâabita, 1/538.

82. Buhârî, "İman", 8; Müslim, "İman", 60-70. 
belirten Kuşadalı İbrahim Halvetî, Peygamber sevgisinin de tam mânâsıyla râbıta sayesinde gerçekleşeceğini belirtmektedir. ${ }^{83}$ Mustafa Fevzi ise râbıtanın aşk ve muhabbet olduğunu, Rasûlullah'ı sevmenin Allah'1 sevmek olduğunu, râbitanın da bu sevgiyi tahakkuk ettirdiğini söylemektedir. ${ }^{84}$

3. "İki müminin ruhu bir günlük mesafede karşılaşıp tanışır; hâlbuki onlar birbirlerini hiç görmemişlerdir." ${ }^{85}$ Bu hadis, mürşidin ruhunun râbıta sırasında gelebileceğine delil getirilmiştir. ${ }^{86}$

4. “Sizin en hayırlılarınız görüldüklerinde Allah’ın hatırlandığı kimselerdir." ${ }^{87}$ Bunlar Allah dostlarıdır ve bunları görmek ya baş gözüyle ya da gönül gözüyledir. Gönül gözüyle görmek râbıtadır. ${ }^{88}$

5. "Kim bir topluluğa benzemeye çalışırsa o da onlardandır." ${ }^{89}$ Râbıta sâlihlere benzemeye çalışmaktır.

6. "Kişi sevdiği ile beraberdir." 90

7. Hasan b. Ali'den rivayet edilmiştir: "Dayım Hind b. Ebî Hâle’den Hz. Peygamber'in hilyesini sordum. Çünkü O, Hz. Peygamber'i en iyi tasvir edenlerden (vassâf-1 nebî) biriydi. Ben de onun Hz. Peygamber'i tasvir etmesini arzuluyordum ki bu vasıfları dikkate alarak Hz. Peygamber'le bağlantı kurabileyim. O da anlatmaya başladı."91

8. “İyi arkadaşla kötü arkadaş misk taşıyan kimse ile körük üfüren kimse gibidir. Misk taşıyan ya sana onu ikram eder yahut sen ondan (miski) satın alırsın ya da ondan güzel bir koku duyarsın. Körük üfüren kimse ise ya elbiseni yakar ya da ondan kötü bir koku duyarsın!”92 Şeyh

\section{Selvi, Rabita, 73.}

84. Mustafa Fevzi, İsbâtü'l-mesâlik, 20-21.

85. Muhammed b. İsmâîl el-Buhârî, el-Edebü'l-müfred, thk. Samir b. Emin (Riyad: Dâru'l-Meârif, 1998), 138 (No. 261); Ebû Abdillâh Ahmed b. Muhammed b. Hanbel, el-Müsned, thk. Şuayb Arnavud vd. (Beyrut: Müessesetü'r-Risâle, 1421/2001), 11/212, 626 (No. 6636, 7047); Ebü'lKāsım et-Taberânî, el-Mu'cemü’l-kebîr, thk. Hamdi Abdulmecid es-Selefî (Kahire: Mektebetü İbn Teymiye, 1405), 13/66; Selvi, Rabita, 74.

86. Hüseyin Avnî, "Râbıtanın Şeri Delilleri”, Darusselam (5 Kasım 2020).

87. Ebû 'Abdillâh Muhammed İbn Mâce, Sünenü İbn Mâce, thk. Muhammed Fuad Abdülbakî (Dâru İhyâi Kütübü’l-Arabî, ts.), "Zühd”, 4 (No. 4119).

88. Selvi, Rabita, 76.

89. Süleyman b. Eş’as b. İshak Ebû Dâvud, Sünenu Ebû Davud. (Beyrut: el-Mektebetü’l-Asriyye, ts.), "Libas", 4.

90. Buhârî, "Edeb”, 96; Müslim, "Birr”, 165.

91. Ebû Îsâ Muhammed et-Tirmizî, eş-Şemâilü’l-Muhammediyye (Beyrut: Dâru İhyâi’t-Turâs, ts.), 22; Gündüz, "Tasavvufî Bir Terim Olarak Râbita”, 44.

92. Müslim, “Birr”, 146. 
güzel koku taşıyan gibidir. Mürit ondan ya soru sorma ya da yanında durmakla istifade eder. ${ }^{93}$

9. "Dünya ve içindekiler lanetlenmiştir. Allah'ı zikir ve Allah'ı zikretmeye (rızasını kazanmaya) götüren şeyler veya âlim (öğreten) yahut talebe (öğrenen) hariç!" ${ }^{\prime 94}$ hadisini râbitaya delil getiren Mustafa Fevzi'ye göre râbıta, hadiste geçen “ مَاوَ الاَهُ / mâ vâlâhu”" "Allah’1 zikretmeye götüren şeyler" kapsamındadır. ${ }^{95}$

10. Efendimizin (s.a.v.) hayâli gözünün önünden hiçbir zaman gitmeyen Hz. Ebû Bekir (ra), bir gün Rasûlullah'a gelerek, “Ey Allah’ın Rasûlü, her zaman hayâliniz gözümün önünde duruyor. Hatta istemediğim bazı yerlerde bile yine sizi hayâl ediyorum" demişti. Peygamberimiz ona tahayyül etmeyiniz diye buyurmamışlardır. ${ }^{96}$

11. "Ali'nin yüzüne bakmak ibadettir." ${ }^{\text {"7 }}$ Madem Hz. Ali'nin yüzüne bakmak ibadet ise giyabında da onun hatıra getirilmesi ibadet olur. ${ }^{98}$

12. "Kim Allah'ın kalbini nurlandırdığı bir kula bakmayı severse, Hârise’ye baksın." ${ }^{99}$

93. Devserî, er-Rahmetü'l-ḩâbita, 1/530.

94. Ebû Îsâ Muhammed et-Tirmizî, el-Câmi'u’l-Kebîr: Sünen-i Tirmizî (Mısır: Mustafa Bâbi'lHalebî, 1975), "Zühd”, 14 (No. 2322); İbn Mâce, “Zühd”, 3 (No. 4112). Elbânî bu hadise yaptı̆̆g talikte hasen olduğunu söylemiştir.

95. Mustafa Fevzi, İsbâtül-mesâlik, 49.

96. Arvâsî, Râbıta-i Şerife, 32; Hâlid el-Bağdâdî, Halidiyye Risalesi, 52; Ahmet Yıldırım, Tasavvufun Temel Öğretilerinin Hadislerdeki Dayanakları (Ankara: TDV Yayınları, 2009), 271. Bizim araştırmamıza göre bu rivayet, Hâlid el-Bağdâdî̀ye ait olan Râbıta hakkındaki risalenin Osmanlıca tercümesinden alınmış ve oraya göre, Hz. Ebû Bekir'e (r.a.) atfedilen bu olayı, Buhârî eserinde zikretmiştir. Fakat böyle bir hadis kaynaklarda bulunmadığı gibi Hâlid el-Bağdâdînnin yazma nüshaları ile matbu nüshasında da bu rivayeti göremedik.

97. Taberânî, el-Mu'cemül-kebîr, 10/76 (No. 10006); Isfahânî, Hillye, 5/58; Ebû Abdillâh Muhammed b. Hâkim en-Nîsâbûrî, el-Müstedrek 'aleș̣-Ṣahịhayn, thk. Mustafa Abdülkādir Atâ (Beyrut: Dâru'lKütübü'l-İlmiyye, 1411/1990), 3/152 (No. 4682-4683). Zehebî yaptı̆̆ı talikte mevzu demiştir 98. Rıfat Okudan, "İnsanî Bir İnsiyak Olarak Râbıta”, Tasavvuf: İlmî ve Akademik Araştırma Dergisi 4/10 (2003), 207. Bu hadisi Okudan, "Huzurunda ve giyabında Ali’nin yüzüne bakmak ibadettir." şeklinde vermiştir. Hadisin aslında olmayan "huzurunda ve giyabında" ilavesi yorum olsa gerektir. Ancak hadisin metni buna izin vermemektedir.

99. Okudan, "İnsanî Bir İnsiyak Olarak Râbıta", 207; Ebû Hâtim Muhammed İbn Hibbân, Kitâbü'l-mecrûhîn mine'l-muḥaddișinn ve'ḍ-ḍ 'afầ' ve'l-metrûkîn, thk. Mahmud İbrâhim Zâyid (Haleb: y.y., 1396), 1/150. İbn Hıbban'ın bu kitabı adından da anlaşılacağı üzere hadis uydurmakla veya zayıf rivayetle meşhur kişiler içindir. Bu hadisin râvisi Ahmed b. el-Hasen b. Eban için de kezzâb (çok yalancı) ve deccal demiş; örnek olarak da bu hadisi zikretmiştir. Yazarın hadisi bu kaynaktan zikretmesi ilginçtir. Hadisin başka kaynakları vardır. bk. Nu'mân b. Sâbit Ebû Hanîfe, el-Frkhü'l-ebsat (İmârât: Mektebetü'l-Furkan, 1419/1999), 123; Nu'mân b. Sâbit Ebû Hanîfe, İmam-ı Azam’ın Beş Eseri, çev. Mustafa Öz (İstanbul: Kalem Yayıncılık, 1981), 52-53; Ebî Bekr b. Muhammed es-Süyûtî, Câmi'u'l-ehâdîș (Mısır. y.y., 1423/2002), 20/398; Ebû Abdillâh 
Bunlar haricinde de pek çok hadis zikredilmiştir. Ancak hepsinin de delâlet yönü çok uzak ve bir bölümü de uydurma olan rivayetlerdir. ${ }^{100}$ Bazı müellifler râbıtanın da tevessül kapsamında olduğunu söyleyerek tevessüle delâlet eden hadisleri de delil olarak zikretmişlerdir. ${ }^{101}$ Burada yer verilen ve verilmeyen sahih hadislerin çoğunluğu Allah için sevme ile ilgilidir. Allah için birini sevenin onu düşüneceği, yani bir çeşit râbıta yapacağı, müridin şeyhini sevmesinin bu kapsamda olduğunu söylemişlerdir.

\subsection{Râbıtanın Câiz Oluşunun Kıyastan Delili}

Râbıtayı savunanlar kıyastan da delil getirmişlerdir. Hâlid-i Bağdâdî râbıtayı Allah'a ulaşmaya vesile olan şeylere kıyas ederek, sakınca olmadığını söylemiştir. Ona göre menedilen râbıta vesilenin maksut kabul edilmesine yol açan, şeyhi maksut görenlerin yaptığ râbıtadır. $^{102}$

Hüseyin ed-Devserî̀nin kıyastan delili şudur: Fakihler namaz kılanın gözünün tabiî sınırlarını taşmamasının sünnet olduğunu, çünkü bunun dikkati toplayıp dağınıklı̆̆ı giderdiğini söylemişlerdir. Aynı şekilde râbıta da ağyarı defeder, huzuru getirir. ${ }^{103}$

Bunun haricinde, Şemâil kitaplarındaki rivayetler nasıl Rasûlullah'ı tasavvur imkânı veriyor ve bu sayede sevgi artıp ittibâ kolaylaşıyorsa râbıta da aynı vazifeyi yapmaktadır; dua ederken vesvese giderilmesi için nasıl bazı şeylerin düşünülmesi tavsiye ediliyorsa, râbıta da aynı faydayı sağlamaktadır gibi kıyaslar da yapılmıştır. ${ }^{104}$

\subsection{Râbıtanın Câiz Oluşuna Serdedilen Psikolojik Deliller}

Râbıtanın câiz oluşuna psikolojiden de deliller getirilmiştir. Bu delili getirenler, râbıta ile doğrudan ilgi kurulamayacak âyet ve hadisler yerine,

\footnotetext{
Muhammed Hakîm et-Tirmizî, Nevâdirü'l-uṣ̂ul fî ma'rifeti ahbâri'r-Resûll, thk. Abdurrahman Umeyre (Beyrut: Dâru'l-Cîl, ts.), 1/270; İbn Hacer el-Askalânî, el-İsâbe fî temyîzi’ṣ-ṣaḥâbe, thk. Adil Ahmed - Ali Muhammed (Beyrut: Dâru'l-Kütübü'l-İlmiyye, 1415), 1/690.

100. Yıldırım, Tasavvufun Temel Öğretileri, 270-280.

101. Hüseyin Avnî, "Râbıtanın Şeri Delilleri” (5 Kasım 2020).

102. Hâlid el-Bağdâdî, Halidiyye Risalesi, 52.

103. Devserî, er-Rahmetü'l-hâhbita, 1/538, 541.

104. Hüseyin Avnî, "Râbıtanın Şeri Delilleri” (5 Kasım 2020).
} 
insanda yaratılıştan bulunan bazı özelliklere vurgu yaparak, râbıtanın insan için tabiî bir husus olduğunu ifade etmişlerdir.

İbn Teymiyye (ö. 728/1328), sevginin tesirini anlatırken, asıl muhabbetin Allah'a olması gerektiğini, Allah'la beraber (Allah'ı sever gibi) kimsenin sevilemeyeceğini, sevginin Allah için olması gerektiğini, Allah için sevmenin Allah'ı sevmek kapsamında olduğunu ifade etmekte ve Allah için sevilen Rasûlullah, önceki peygamberler ve bunların ashabı sâlihler kalpte tasavvur edildiğinde bunun kişinin kalbini Allah sevgisine götüreceğini söylemiştir. ${ }^{105}$

Ömer Dağıstanî, râbıtanın sevgi ve aynîleşme yönüne dikkat çekmiş, kendisini şeyhine, Hz. Peygamber'e veya Cenâb-1 Hakk'a gerçek mânâda bağlayan, onlarla kalbî ve mânevî bir irtibat kuran sâlikin, bu râbıtası sayesinde yalnızken de sanki onların huzurundaymış gibi edepli ve terbiyeli hareket etmeye gayret ederek feyz kazanmaya çalışı, böylelikle mâsiyet ve kötülüklerden uzaklaşmaya gayret edeceğini, gerçek râbıtanın da bu olduğunu söylemiştir. ${ }^{106}$

Râbıtanın psikolojik tesirine dikkat çeken sûfîlere göre, tasavvuftaki râbıta için bu durumları bir delil gibi sunmaya gerek yoktur. Bunlar, râbıtanın fitrî bir olay olarak insanın varlığına zaten yansıdığını göstermektedir. ${ }^{107}$

Rıfat Okudan'a göre râbıta, psikolojik bir eğitim yöntemidir ve sevgi yoluyla kâmil insanlarla özdeşleşme için kullanılmaktadır. ${ }^{108}$ Ona göre râbıtasız insan olmaz ve olamaz. Çünkü münasebetsiz, alakasız ve irtibatsız bir sosyal hayat düşünülemez. ${ }^{109}$ Bugün sosyal bilimlerde de tespit edilmiş olunduğu üzere, örnek alınan her enerjik karakterde bir bulaşma özelliği bulunmakta, kuvvetli insanlar zayıf olanlar için bir ilham kaynağı olmaktadır. ${ }^{110}$ Benimseme, benzeme ve özdeşleşme ameliyesinden gerek psikolojide gerek eğitim psikolojisinde ve gerekse sosyal psikolojide geniş ölçüde faydalanılır. Râbıta da insanî bir insiyak olan bu temayülün dinin

105. Ebü'l-Abbâs Takıyyüddîn Ahmed İbn Teymiyye, Mecmû́u'l-fetâvâ, thk. Abdurrahman b. Muhammed (Medine: Mecmeu'l-Melik, 1416-1995), 10/607-608.

106. Dağıstânî, Fetvalar, 150-152.

107. Taşpınar, Tasavvufta Mürşid Rabıtası, 50; Sevim Arslan, "Muhabbet Râbıtası”, Eskişehir Osmangazi Üniversitesi İlahiyat Fakültesi Dergisi 2/3 (Aralık 2015), 58, 68.

108. Okudan, "İnsanî Bir İnsiyak Olarak Râbıta”, 214.

109. Okudan, "İnsanî Bir İnsiyak Olarak Râbita”, 204.

110. Okudan, "İnsanî Bir İnsiyak Olarak Râbita”, 203. 
fert ve toplum hayatında gereği gibi yaşanabilmesi için kullanılmasından başka bir şey değildir. ${ }^{111}$

Gündüz, insan psikolojisinden kaynaklanan ve tüm kültürlerde bulunan, yüksek özellikleri bulunanlarla aynîleşmek, onlara benzemek düşüncesinin İslâm toplumunda "râbıta" ile müesseseleştiği kanaatindedir. ${ }^{112}$ $\mathrm{Bu}$ delili getirenler genellikle râbıtanın örnek alma, benzemeye çalışma yönlerini ön plana çıkarmışlardır.

\subsection{Râbıtayı Savunmak İçin Kaynak Gösterilen Âlimler ve Sözleri}

Râbıta lehine eser yazanlar dört mezhep ulemâsının râbıtaya cevaz veren sözler söylediğini iddia etmişler ve bunları nakletmişlerdir. Bu hususta ilk eseri kaleme alan Hâlid-i Bağdâdî̀nin konuya dair yazdıkları daha sonra kaleme alınan eserlerin hepsine kaynaklık etmiştir. ${ }^{113}$ Buna göre:

Hanefîlerden Ekmelüddin Bâbertî (ö. 786/1384), "Şerhu’l-Meşârik" kitabında, "Kim rüyasında beni görürse, uyanık iken de görecektir. Şeytan benim sûretime giremez"114 hadisinin şerhinde bir kişi ile uyanık ve uyku halinde buluşmanın beş yolla olacağını, bu yolların muhabbetle kuvvetleneceğini söylemiştir. Ona göre kim bu beş usulü oluşturursa geçmiş ruhlarla bağlantı kurabilir. ${ }^{115}$ Seyyid Şerif Cürcânî (ö. 816/1413), Mevâkıf kitabının şerhinin sonunda İslâmî fırkaları anlatmadan hemen önce ve Şerhu'l-Metali` kitabının hâş̧iyesinin başlarında, ölümlerinden sonra bile velîlerin sûretlerinin müritlere görünmesi ve müritlerin onlardan feyz alabilmelerinin sahih olduğunu söylemektedir. ${ }^{116}$ Hamevî,

111. Okudan, "İnsanî Bir İnsiyak Olarak Râbıta”, 205.

112. Gündüz, "Tasavvufî Bir Terim Olarak Râbıta”, 23-26.

113. Osmanlı’nın son döneminde Nakşî-Hâlidî şeyhlerin râbıta hakkındaki delil ve savunmalarına dair ayrıntılı bilgi için bk. M. Brett Wilson, "Binding with a Perfect Sufi Master: Naqshbandī Defenses of rābita from the Late Ottoman Empire to the Turkish Republic”, Die Welt des Islams 60/1 (Mart 2020), 56-78.

114. Buhârî, “Ta’bir”, 10 (No. 6993); Müslim, Müslim, "Rüyâ”, 11 (No. 2266).

115. Ebü’l-Fazl Celâlüddîn Abdurrahmân b. Ebî Bekr es-Süyûtî, el-Hâtvîli’l-fetâvî (Beyrut: Dâru'lFikr, 1424/2004), 2/311; Hâlid el-Bağdâdî, Risâle fî̀r-Râbıta (Yazmalar Koleksiyonu, 6129/9), 54a. 116. Hâlid el-Bağdâdî, Risâle fî̀r-Râbıta (Yazmalar Koleksiyonu, 6129/9), 55a-b; Hâlid el-Bă̆dâdî, er-Risâletü’l-Hâlidiyye, 28-29; Hasan Hilmi, es-Sifrü’l-esnâ, 100. Seyyid Şerif el-Cürcânî, Şerḥu Mețâli‘a yaptığı hâşiyede, Rasûlullah'la tevessül edilmesinin vefatından sonra da devam ettiğini, ondan gelen feyzi onu ziyaret eden basiret sahiplerinin gördüğünü söylemektedir. bk. Ebû Abdillâh Muhammed Kutbüddin er-Râzî, Şerḥu Mețâli'i’l-envâr, nşr. Zevi'l-Kurbâ (Kum: 
(öl. 1098/1687), evliyanın da dahil olduğu küllî ruhların dünyada yetmiş bin sûrete girebileceğini, bu durumun berzah aleminde iken öncelikle olacağıını söylemiştir. ${ }^{117}$ Ebû Saîd Hâdimî (ö. 1175/1762), Nakşibendî usulüne dair yazdığı risalede, zikir esnasında tamamen Allah'a yönelmek için uğraşan müride bir dağınıklık, vesvese veya kabz hali gelirse, soğuk veya sıcak su ile gusül veya abdest alıp hacet namazı kılmasını, istiğfar ve dua ile haline yönelmesini, bunlarla def imkânı olmazsa o zaman Nebî aleyhisselâm veya şeyhin sûretini hayal etmesini tavsiye etmektedir. ${ }^{118}$

Şâfîilerden İmam Gazzâlî (ö. 505/1111) ile İbn Hacer el-Heytemî (ö. 974/1576) namazda Tahiyyat okurken "esselâmu 'aleyke eyyühennebî" derken, Rasûlullah yanında gibi düşünmeyi tavsiye etmişler; ${ }^{119}$ Şehâbeddin Sühreverdî, "bu sırada kalp gözünde Râsûlullah'ı canlandırır" demiştir. ${ }^{120}$ Süyûtînnin (ö. 911/1505) naklettiğine göre, İbn Abbas (r.a.) rüyasında Rasûlullah'ı gördükten sonra müminlerin annelerinin birinin yanına gidip rüyasını anlatınca, o Râsûlullah'ın aynasını İbn Abbas'a vermiş, İbn Abbas bu aynaya bakınca kendini değil Rasûlullah'ı görmüştür. ${ }^{121}$ Hâlid-i Bağdâdî̀ye göre "sûfîlerin ıstılahında râbıtada fenâ dedikleri işte budur." Bunun sadece Rasûlullah'a hasredilemeyeceğini, çünkü bunun hasâisten olmadığını, bu hususun Rasûlullah ile evliya arasında müşterek olduğunu ancak namazda Rasûlullah'tan başkasını muhatap almanın namazı

y.y., 1394), 1/24. Şerḥu'l-Mevâkııf ta da Bayezid-i Bistâmî'nin Cafer-i Sâdık'ın ruhaniyetinden feyz aldığını söylemektedir. bk. Seyyid Şerîf el-Cürcânî, Şerḥu’l-Mevâkııf, haz. Mahmud Ömer ed-Dimyâtî (Beyrut: Dâru'l-Kütübü'l-İlmiyye, 1998), 8/404. Bu iki görüş haricinde Hâlid el-Bağdâdî’nin nakline yakın bir metin bulamadık.

117. Ebü'l-Abbâs Şihâbüddîn Ahmed b. Muhammed el-Hamevî, Nefehâtü'l-ḳurb ve'l-ittiṣâl bi-iśbâti't-taṣarruf li-evliyâ'illâhi ve'l-kerâmeti ba'de'l-intikāl (Kahire: Dâru Cevâmii'l-Kelim, ts.), 83-84. Hamevî bu eserinde evliyanın ruhunun çeşitli suretlere hem bu dünyada hem berzah âleminde iken girebileceğini, Şa 'ranı̂'den alıntılarla vefatından sonra bir velîden istimdat edilebileceğini, velînin ölümünden sonra bile tasarrufunun olduğunu söylemiştir. bk. Hamevî, Nefehâtüll-kurb, 82-88.

118. Ebû Saîd Muhammed Hâdimî, er-Risâletü’n-Nakşibendiyye (Balıkesir, Balıkesir İl Halk Kütüphanesi, 10 Hk 369/6), 114b-115a. Kütüphane kataloğuna “et-Tarîkatu'n-Nakşibendiye” adıyla kaydedilmiştir. Ayrıca bk. Fevzi Efendi, 'Aynü’l-hakîkka, 22; Mustafa Fevzi, İsbâtü’l-mesâlik, 35. 119. Ebû Hâmid el-Gazzâlî, İhyâu ulûmi'd-dîn (Beyrut: Dârü'l-Ma'rife, ts.), 1/169; Ebü'l-Abbâs Şihâbüddîn Ahmed b. Muhammed İbn Hacer el-Heytemî, ed-Dürrü’l-mendûd fi'ṣ-șalât ve's-selâm 'alâ șâhibi'l-makāmi'l-maḥmûd (Cidde: Dâru'l-Minhâc, 1426), 114.

120. Şehabeddin Sühreverdî, Avârif, 2/131; Şehabeddin Sühreverdî, Gerçek Tasavvuf, 405; Hâlid el-Bağdâdî, Risâle fî̀r-Râbıta (Yazmalar Koleksiyonu, 6129/9), 54b.

121. Süyûtî, el-Hâvî li’-fetâvî, 2/308. 
bozacağını, bunun sadece Rasûlullah'a ait bir husus olduğunu söylemiştir. ${ }^{122}$ Şemsüddin Sefîrî (öl. 956/1549), ${ }^{123}$ "Rasûlullah'ın sûretine şeytan giremeyeceği gibi, silsile halinde icazeti Rasûlullah'a dayanan irşada mezun şeyhin sûretine de şeytan giremez." demektedir. Zeynüddin Ebû Bekir el-Harrânî'nin ${ }^{124}$ vasiyetinden yaptığı aktarmada da halvete giren bir müridin muhakkak şeyhinin huzurunda bu işi yapmasını; şeyhine râbıtası (bağlantısı) tam olan müridin sıkıntılarını şeyhin çözeceğini söylemektedir. ${ }^{125}$

Hanbelîlerden, Abdülkādir Geylânî (öl. 561/1165-66), mürit ile şeyhi arasındaki kalbî bağlantının istifade için yeterli olduğunu; ${ }^{126}$ İbn Kayyim el-Cevziyye (öl. 751/1350), Kitâbu'r-Rûh'unda, ruhun bedenle bağlantısını anlatırken, "(öldükten sonra) ruh refîk-i a'lầda olsa bile beden ile bir bağlantısı bulunur ve kendisine selâm verildiğinde buna cevap verir”127 demektedir. Hâlid-i Bağdâdî bu sözü evliyanın öldükten sonra da tasarrufu olduğuna delil getirmiştir. ${ }^{128}$

Süyûtînnin naklettiğine göre Mâlikîlerden el-Muhtasar sahibi Halil el-Cündî (öl. 776/1374?), velâyeti kesinleşen velînin ruhaniyetinin çeşitli sûretlere girebileceğini söylemiş;; ${ }^{129}$ Ebu'l-Abbas el-Mürsî (ö. 685/1287)

122. Hâlid el-Bağdâdî, Risâle fî̀r-Râbıta (Yazmalar Koleksiyonu, 6129/9), 54b-55a.

123. Sefîrî Şafî̀ bir âlimdir. Eseri asıl olarak vaaz ve irşad için yazılmış olup Buhârînin kısmî şerhi mesabesindedir. Müellif, eseri yazarken çok sayıda tasavvuf kaynağından istifade etmiştir. bk. Hızır Yağcı, “Sefîrî ve Buhârî Şerhi”, Diyanet İlmi Dergi: Diyanet İşleri Reisliği Yıllığı 54/3 (2018), 39-57. Sefîrînin peygamber tasavvuru tasavvufî anlayışla uyumludur. bk. Yağcı, "Sefîrî ve Buhârî Şerhi”, 55.

124. Bu zât Zeynüddin Hâfî (ö. 838/1435) olmalıdır. Çünkü eserde el-Horasânî nisbesi de vardır. Ancak Zeynüddin el-Hâfî̀nin Harrânî nisbesi bilinmemektedir. Hatta Horasânî nisbesi de kullanılmamaktadır. bk. Reşat Öngören, "Zeynüddin el-Hâfî”, Türkiye Diyanet Vakfi İslâm Ansiklopedisi (İstanbul: TDV Yayınları, 2013), 44/375-377.

125. Şemsüddîn Muhammed b. Ömer es-Sefîrî, el-Mecâlisü’l-va'ziyye fî şerhi ehâdîsi hayri'l-beriyye min Sahîhi'l-İmâmi'l-Buhârî, thk. Ahmed Fethi Abdurrahman (Beyrut: Dâru'l-Kütübü'lİlmiyye, 2004), 1/195.

126. Şehabeddin Sühreverdî, Avârif, 2/212; Şehabeddin Sühreverdî, Gerçek Tasavvuf, 529.

127. Bu alıntıyı doğrudan İbn Kayyim'den değil de Süyûtî'den yapmıştır. Kitâbu'r-Rûh'taki ibare biraz farklıdır ancak aynı mânâya gelmektedir. bk. İbn Kayyim el-Cevziyye, Kitâbu'r-Rûh (Beyrut: Dâru'l-Kütübü'l-İlmiyye, ts.), 102.

128. Hâlid el-Bağdâdî, Risâle fî̀r-Râbıta (Yazmalar Koleksiyonu, 6129/9), 56a; Hâlid el-Bağdâdî, Halidiyye Risalesi, 29.

129. Süyûtî, el-Hâvî li’-fetâvî, 1/258. Süyûtî’nin aktarmasına göre bu ifade Halil el-Cündî’nin hocası Abdullah el-Menûfî (ö. 749/1348) için yazdığı menâkıbda geçmektedir 
ile İbn Atâullah el-İskenderî̀den de (öl. 709/1309) bu minvalde sözler aktarılmıştır. ${ }^{130}$

Bunun haricinde Molla Câmî (ö. 898/1492), İsmâil Hakkı Bursevî (ö. 1137/1725), ${ }^{131}$ İbn Âbidin (ö. 1252/1836) ${ }^{132}$ ve müfessir Şehâbeddin

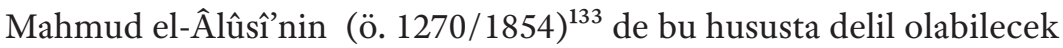
ifadelerinin bulunduğu iddia edilmiştir.

\subsection{Râbıtanın Cevazına Dair Sunulan Delillerin Değerlendirmesi}

Râbıtanın câiz ve gerekliliği konusunda delil olarak sunulan âyetlerin başında, "Sâdıklarla beraber olunuz!" ve “vesile arayınız...” âyetleri gözükmektedir. Râbıtanın sâdık biriyle mânen beraber bulunmak olduğu kabul edilirse, Ubeydullah Ahrar'ın tefsiri yerinde olmaktadır. Allah'a ulaştıran tüm yollar bir vesile olduğuna göre râbıta da Allah'a ulaşmada bir vesile ise ilgili âyetin şümûlüne girmesi gerekir. Ancak sâdıklarla beraber olma emri, mânen beraber olmayı kapsasa bile bunun şeyhlere tahsis edilmesini gerektiren bir muhassis olmadığı gibi, mânen beraber olma râbıtanın ancak bir çeşidini ifade etmektedir. Vesile âyetine râbıtanın girdirilmesi ise bizzat râbıta hakkında ifade edilen, râbıtanın ibadet olmadı̆̆ı, belli bir düzeye gelen kişi tarafından bırakılması gerektiği görüşleri ile çelişmektedir. Çünkü Allah’a ulaşmaya vesile olan şeyler ibadet veya fazilet kapsamındadır. Eğer râbıtayı bu vesilelerden biri olarak değerlendirirsek, râbıtanın ancak bazı çeşitlerini bu kapsamda değerlendirmemiz gerekir.

Râbıtaya delil getirilen âyetlerden "eğer Allah'ı seviyorsanız..." ve "üsve” âyetleri genel mânâda ittibâ ve örnek almaktan bahsetmektedir. Bu hususta şeyhlerin bir ayrıcalığ olmadığg gibi sûfîlerin tanımladığg gibi bir râbıtaya da ihtiyaç yoktur. Yûsuf sûresinde geçen "burhân"1n Hz. Yâ' 'kūb’un temessülü olduğu rivayeti muhakkik müfessirler tarafindan

130. Hâlid el-Bağdâdî, Risâle fî̀r-Râbıta (Yazmalar Koleksiyonu, 6129/9), 56a-b.

131. Fevzi Efendi, 'Aynül-hakîka, 22.

132. Mustafa Fevzi, İsbâtü'l-mesâlik, 37.

133. Ebü's-Senâ Şihâbüddîn Mahmûd el-Âlûsî, el-Feyżü'l-vârid 'alâ ravżi Meršiyyeti Mevlânâ Hâlid, thk. Ahmed Ferid el-Mezîdî (Beyrut: Dâru'l-Kütübü'l-İlmiyye, 2010), 149-151; Hasan Hilmi, es-Sifrüll-esnâ, 92. 
kabul edilmemiştir. ${ }^{134}$ Rivayet kabul edilse bile bir peygamberin mucizesi olur ki, diğer insanlara delil olarak alınması uygun değildir. "Salâtü selâm" âyeti ile Mehmed Fevzi'nin farklı zikrettiği iki âyetin ise delâleti çok uzaktır.

Râbıta için hadisten getirilen delillerden yukarıda aktardığımız rivayetlerden, "Sizin en hayırllarınız..." ve "İyi arkadaşla kötü arkadaş misali..." hadisleri râbıtanın bir çeşidi olan, şeyhini sevmek ve onu düşünmeye delil olmaya elverişlidir. "Ameller niyetlere göredir...", "Ben sizden birine..." ve "Dünya ve içindekiler lanetlenmiştir..." hadisleri ise çok genel hadislerdir. Râbıtanın bu hadislerin kapsamına girebilmesi için öncelikle meşruiyetinin ispatlanması gerekir. Hz. Ebû Bekir'e atfedilen rivayet eğer sahih olsa idi belki şeyhin sûretini düşünmek mânâsına râbıtaya daha güçlü bir delil olabilirdi. Ancak böyle bir hadis bilinmemektedir. Ayrıca sıhhati kabul edilse bile Hz. Ebû Bekir bunun gayri ihtiyarî olduğunu söylemiştir. "Alinin yüzüne bakmak ibadettir." rivayetinin sihhati problemlidir. Her ne kadar Ebü’l-Feyz İbnü’s-Sıddîk (1902-1960) hadisin sahih hatta toplam rivayetinin mütevatir derecesine çıktığını söylese de ${ }^{135}$ İbn Adî (ö. 365/976) hadisin ravilerinden Ebû Saîd el-Adevînin ehlibeyt adına hadis uyduranlardan olduğunu söyleyerek hadise bâtıl demiş; ${ }^{136}$ İbnü'lCevzî (ö. 597/1201), hadisin tüm tariklerini zikretmiş ve hiçbir yolunun sahih olmadığını söylemiştir. ${ }^{137}$ Aynı şekilde Hârise hadisinin sıhhati de problemlidir. ${ }^{138}$ Ayrıca sahih kabul edilseler bile bu zatların giyaplarında sûretlerini düşünmeye dair hadislerde bir delil bulunmamaktadır. Belki buradan sâlih zatların yüzlerine bakmanın tavsiye edilen bir husus olması çıkarılabilir. Kısaca söylemek gerekirse delil getirilen hadisler de âyetler gibi ancak şeyhi sevme ve örnek alma mânâsındaki râbıta çeşitlerine delil olmaya elverişli olup diğer râbıta çeşitlerine delil olmaya elverişli değildir.

134. Fahreddîn er-Râzî, Mefâtîhu'l-ġayb: et-Tefsîrü'l-kebîr (Beyrut: Dâru İhyâi't-Turâsi'l-Arabî, 1420), 18/440-444.

135. Ebü’l-Feyz İbnü>s-Siddîk, Alî b. Ebî Tâlib imâmü’l-'ârifîn (Kahire: Matbaatü’s-Seâde, 1389/1969), 222-224; Hüseyin Avnî, "Râbıtanın Şeri Delilleri” (5 Kasım 2020).

136. Ebû Ahmed Abdullāh İbn Adî, el-Kâmil fî dúcafầ'’r-ricâl, thk. Âdil Ahmed - Ali Muhammed (Beyrut: el-Kütübü'l-İlmiyye, 1418/1997), 3/195-196.

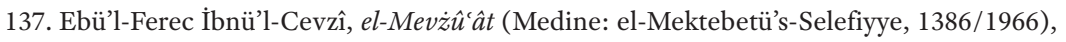
1/358-361.

138. Ebü'l-Fazl Zeynüddîn Abdürrahîm el-Irâkī, el-Mugnnî 'an hamli’l-esfâr fi’l-esfâr fî̀ tahrîci mâ fi'l-İhyâ'i mine'l-ahbâr (Riyad: Dâru'l-Âsime, 1408/1987), 5/2272-73. 
Râbıta için yapılan kıyaslarda vesveseyi gidermek, zihni toplamak mânâsına vurgu yapılmıştır. Bunun râbıta ile olacağına dair tecrübeden başka bir delil bulunmamaktadır. Tecrübeye dayanan bir hususun da k1yas delili içinde değil de psikoloji delili içinde zikredilmesi daha uygundur. Kıyasla râbıtanın gerekliliği değil, belki mubahlığı ortaya konabilir.

Kendisinden râbıta lehine delil olabilecek sözler nakledilen âlimlerin tamamına yakını tasavvufla ya mürit ya şeyh olarak bağlantısı olan âlimlerdir. Buna rağmen bunlardan sadece Ebû Saîd Hâdimî ile Şa'ranî şeyhin sûretini düşünerek râbıta yapmayı açıkça belirtmiştir. Diğerlerinin önemli bölümünün Nakşî olduğu dikkate alındığında râbıtayı bildikleri ve reddetmedikleri kanaati yanlış olmaz. Ancak şeyhin sûretini düşünmek mânâsındaki râbıta hakkında bir sözleri bulunmamaktadır. Ebû Saîd Hâdimî ile Şa ranî̉nin sözlerinde de râbıtanın çeşitlerinin tamamı ile ilgili bir açıklama bulunmamaktadır.

Râbıtanın en güçlü delili olarak psikoloji delili gözükmektedir. Tosun'un ifadesiyle râbıtayı ayrıntıdan ve kurallardan arındırarak şeyh ile mürit arasında tabiî ve psikolojik bir iletişime dönüştüren bu yaklaşım konuyla ilgisi oldukça az olan âyet ve hadisleri delil olarak kullanmaktan daha sağlıklıdır. ${ }^{139}$ Ancak bu delilin de sadece muhabbet râbıtası ile mürşidi yanında düşünmek ve onu örnek almak mânâsındaki râbıtaları içerdiğini gözden kaçırmamak gerekir.

\section{Râbıta Üzerinde Gerçekleşen Tartışmalar}

19. asra kadar râbıtaya karşı çıkan bir âlim bilinmemektedir. Bu durum râbıtanın o döneme kadar yanlış uygulamasının olmadığı veya yaygın olarak bilinmediğinden kaynaklandığı gibi Muhammed b. Abdülvehhâb (ö. 1206/1792) ile ortaya çıan neo-selefî düşüncenin etkisi ile tartışılmaya başlanmasından da kaynaklanabilir. Râbıtaya karşı çıkanların ekserisinin kimlikleri son ihtimalin daha kuvvetli olduğunu göstermektedir. Râbıtanın tartışma konusu haline gelmesinin ilk olarak Hâlid-i Bağdâdî döneminde olduğunu, bu dönemde râbıtayı savunmak üzere kaleme alınan risalelerden anliyoruz. 
Râbıta aleyhinde en kapsamlı yazan ilk kişi İstanbul'da Hâfız Seyyid Hoca'dır. ${ }^{140}$ Risalesini müteahhir bazı câhil mutasavvıfların ihdas ettiği râbıtayı iptal için yazdığını söyleyen Seyyid Hoca, ${ }^{141}$ râbıta yapanlara çok şiddetli yüklenmiştir. Bununla birlikte o râbıtanın tüm çeşitlerine karşı değildir. O, karşı çıktığı hususun farz, vâcip veya müstehap olsun mutlak mânâda ibadet içinde yapılan râbıta olduğunu, muhabbet râbıtası ile mânevî râbıtaya bir şey demediğini ifade etmektedir. ${ }^{142}$ Seyyid Hoca, Nakşibendîler'den bazılarının râbıta, mânevî bağ ve muhabbettir, namazda ve zikirde şeyhin sûretini düşünmek değildir, dediklerini, böyle olduğu zaman arada bir çekişme kalmayacağını; zamanındaki Nakşîlerin üç kısım olduğunu; birinci grubun hem namazda hem de zikirde şeyhin sûretini düşündüklerini; ikinci grubun sadece zikirde düşünüp namazda düşünmediklerini, üçüncü grubun ise ikisinde de bunu kabul etmediklerini; bu üçüncüsünün şeriatta sahih diğer ikisinin ise batıl olduğunu söylemektedir. ${ }^{143}$

Seyyid Hoca, râbıtayı ret sadedinde, "Onlar ahbar ve ruhbanlarını Allah'tan başka rab ittihaz ettiler"144 Allah'a ortaklar koşmayı!"”145 ve "Biz onlara ancak bizi Allah'a yaklaştırsin diye ibadet ediyoruz"1166 âyetlerini delil getirmiştir. Ona göre namaz, zikir gibi ibadetlerin içinde yapılan râbıta, haramı helal kılma kapsamındadır. ${ }^{147}$ Namaz kılarken ve zikir sırasında râbıta yapan biri ibadet içinde şeyhe tazim edip kendi nefsini de tezellül

\footnotetext{
140. Hakkında fazla bilgi bulunmayan Hâfız Seyyid Hoca, zamanının müderrislerinden ve Ahmet Cevdet Paşa'nın (ö.1895) hocalarından olup özellikle Arapçası çok kuvvetli âbid, zâhid, âlim bir zat imiş. Ancak sûfîlerin bir kısım yollarını, özellikle râbıtayı şiddetle inkâr edermiş. bk. Ahmed Cevdet Paşa, Tezâkir, haz. Cavid Baysun (Ankara: Türk Tarih Kurumu Yayınları, 1991), 4/8-9, 15-16.

141. Yazılanlardan anlaşıldığı kadarıyla Seyyid Hoca ilk olarak Türkçe (Osmanlıca) bir risale kaleme almış, buna karşın Edirne Müftüsü Mehmed Fevzi, 'Aynü’l-hakâika adı ile bir reddiye yazmıştır. Bundan sonra Seyyid Hoca Arapça bir risale kaleme almıştır. Biz Osmanlıca risaleyi bulamadık. Esas aldığımız Ahmed Nureddin b. Mehmed Emin tarafından 1345/1927 yılında istinsah edilen (künyeye istinsah tarihi yanlışlıkla 1245/1828 yazılmıştır) nüshanın sonunda "İş bu mahalle değin tahrir edilen ibârât merhum Hâfız Seyyid Efendi’ye tesbit edilen risaledir” ibaresi bulunmaktadır.

142. Hâfız Seyyid Hoca, Şerhü Risâle ibtâli’r-râbıta (Manisa İl Halk Kütüphanesi, Akhisar Zeynelzade, 45 Ak Ze 1518/1), 9-11.

143. Seyyid Hoca, İbtâli’r-râbıta (Akhisar Zeynelzade, 1518/1), 16.

144. et-Tevbe $9 / 31$.

145. el-Bakara $2 / 22$.

146. ez-Zümer 39/3.

147. Seyyid Hoca, İbtâli’r-râbıta (Akhisar Zeynelzade, 1518/1), 2-3.
} 
içinde görmektedir ki, bu küfürdür. ${ }^{148}$ Müridin namazda Allah'a ulaşmak için şeyhin sûretini zihninde tutması putlara ibadet etme kapsamına girmektedir. Zikir de aynı şekildedir. Çünkü zikretmek isteyen mürit bunu ancak ibadet kastıyla yapar. ${ }^{149}$ Seyyid Hoca, râbıta ile namazda kalbe gelen vesvesenin giderildiği sözünü şiddetle reddetmiş, namazda gelen vesvesenin îmânın delili olduğunu, kafirlerin kalbine vesvese gelmediğini iddia etmiştir. Ona göre şeytan kafirlerle uğraşmaz, müminlerle uğraşır. ${ }^{150}$ Zikir de aynı kapsamdadır ve bu sebeple zikir esnasında havâtırı def için şeyhin sûretini zihinde tutmak da batıldır ve küfürdür. ${ }^{151}$

Edirne Müftüsü’nin, Şa'rânî, Molla Câmî, İsmail Hakkı, Ekmelüddin Bâbertî, İbn Hacer, Seyyid Şerif Cürcânî̀den yaptığı nakillerin yalan olduğunu iddia eden Seyyid Hoca, Hadimî'den nakledilen “Nebî̀nin sûreti” "şeyhin sûreti” ifadesinin de muhabbet ve mânevî râbıta ${ }^{152}$ olarak anlaşılması gerektiğini söylemektedir. ${ }^{153}$

Râbıta aleyhine yazanlardan Sıddîk Hasan Han (ö. 1307/1890) tefsir sahibi Mahmûd el-Âlûsînnin oğlu Hayreddîn Nu'mân el-Âlûsîye (ö. 1317/1899) ${ }^{154}$ ayırdığı bölümde bu zattan aldığı bir mektubun metnini nakletmektedir. Buna göre Hayreddin Âlûsî, Nakşibendi râbıtası hakkında Sıddık Han'ın görüşünü öğrenmek istemektedir. Sıddık Han buna verdiği cevapta, Şah Veliyyullah Dihlevînin el-Kavlü'l-Cemîl kitabında râbıtayı açıç̧a nehyettiğini iddia etmekte; Muhammed İsmail ed-Dihlevî̀nin "es-Strât'ul-Mustakîm" adlı kitabından, "râbıta şirktir" ifadesini aktarmakta ve en sonunda râbıtanın, mutasavvifenin (tasavvufçuluk oynayanların) Kur'ân sünnette bir esası olmadan uydurduğu çirkin bir bidat olduğunu söylemektedir. ${ }^{155}$

Neo-selefî düşüncede olanlar veya ondan etkilenenler, râbıtayı bir ibadet olarak algılamışlar ya sadece şirk demişler ${ }^{156}$ ya da hem bidat hem

148. Seyyid Hoca, İbtâli’r-râbıta (Akhisar Zeynelzade, 1518/1), 4.

149. Seyyid Hoca, İbtâli'r-râbıta (Akhisar Zeynelzade, 1518/1), 7-9.

150. Seyyid Hoca, İbtâli’r-râbıta (Akhisar Zeynelzade, 1518/1), 5.

151. Seyyid Hoca, İbtâli’r-râbıta (Akhisar Zeynelzade, 1518/1), 6.

152. Normal zamanlarda şeyhi düşünmek mânâsındadır.

153. Seyyid Hoca, İbtâli’r-râbıta (Akhisar Zeynelzade, 1518/1), 12.

154. Fıkıh ve kelam âlimi olan bu zat akaidde Selefî, fikıhta Hanefî' dir. bk. Yusuf Şevki Yavuz, "Âlûsî, Nu'mân b. Mahmûd”, Türkiye Diyanet Vakfi İslâm Ansiklopedisi (İstanbul: TDV Yayınlar1, 1989), 2/549. 155. Ebü't-Tayyib Sıddîk Hasan Han, et-Tâcü'l-mükellel min cevâhiri me'âsiri't-tırazi'l-âhiri ve’l-evvel (Katar: Vezâretü'l-Evkâf, 2007), 511-512.

156. Abdülaziz Bayındır, Kur'ân Işı̆̆ında Tarikatçılı̆̆a Bakış (İstanbul: Süleymaniye Vakfı Yayınlar1, 2015), 166, 168. 
de şirkin bir çeşidi telakki etmişlerdir. ${ }^{157}$ Ferit Aydın ise bu ithamı ileri boyuta götürerek râbıtayı Budizm'den alınmış, ${ }^{158}$ yoga örnek alınarak geliştirilmiş ${ }^{159}$ bir tür ibadet şeklinde değerlendirmiştir. Ona göre Hâlid-i Bağdâdî, Brahmanist bir İslâm anlayışı yaymaya çalışmaktadır ve bunun en önemli aracı da râbıtadır. ${ }^{160}$ Bunun haricinde râbıtayı toptan reddetmeyip şeyhin sûretini düşünmek anlamındaki râbıtayı reddedenler ${ }^{161}$ ile Allah'a yaklaşmak için sağlıklı bir yol kabul etmeyenler de vardır. ${ }^{162}$

Râbıtayı reddedenlerin tamamı râbıta için istişhâd edilen âyet ve hadislerin bu mânâda delil olamayacağını öne sürmüşlerdir. Onlara göre râbıta ile ilgili herhangi bir âyet ve hadis bulunmamaktadır. Râbıtayı bidat veya şirk olarak kabul edenlerin şöyle bir mantık silsilesi izlediği anlaşılmaktadır: Râbıta bir ibadettir. Bir ibadet ancak nas ile konabilir. Kur'ân ve sünnette râbıta ile ilgili bir delil yoktur. Râbıta hakkında bir delil olmadığına göre eğer bu Allah için yapılırsa bidat, şeyh için yapılırsa şirk olur.

\subsection{Râbıtayı Savunanların Eleştirilere Cevapları}

Yukarıda söz konusu olan ithamlara râbıtayı savunanlar tarafından çeşitli cevaplar verilmiştir. Mehmed Fevzi, râbıtanın şirk olmadığını, çünkü İslâm'ın dışında bir şey olmadığını ve muhlis müritlerin Allah’a ulaşmak için bu yolu tuttuklarını; bidat de olmadığını çünkü sahabenin râbıta yaptığını iddia etmiştir. ${ }^{163}$

Geçmiş kavimlerin putlara tapma sürecinin tefsirlerde yer aldığ́nı söyleyen Mehmed Fevzi, râbıta yapan bir müridin bu kapsamda

\footnotetext{
157. Mirfet bt. Kâmil b. Abdillah, “er-Râbițatü’n-Naksşibendiyye”, Havliyye Külliyeti’d-Dirâsâti’lİslâmiyye el-Arabiyye li’-Benât İskenderiye 34/5 (Aralık 2018), 1110, 1121.

158. Ferit Aydın, Tarikatta Rabıta ve Nakşibendilik (İstanbul: Süleymaniye Vakfı Yayınları, 2000), 60. Bu eser râbıta hakkında ciddi bir araştırma görünümü verse de yazar râbıtayı vesile ederek başta Hâlidî kolu olmak üzere Nakşibendiliği, oradan da tasavvufu mahkûm etmeye çalışmaktadır. Ona göre Türkler saf İslâm’ı almak istememektedirler ve Nakşîlik alternatif bir dindir bk. Aydın, Tarikatta Rabıta, 66-68. Türk toplumunun çoğunluğu insanı tanrılaştırma inancındadır ve toplumda çok az Hanif bulunmaktadır bk. Aydın, Tarikatta Rabıta 223. Vehhabîler'in başlattığ hareket bir tevhid hareketidir ve öldürdükleri de müşriktir bk. Aydın, Tarikatta Rabıta, 224-225. 159. Aydın, Tarikatta Rabıta, 244-248.

160. Aydın, Tarikatta Rabita, 156, 252.

161. Süleyman Ateş, İslâm Tasavvufu (İstanbul: Yeni Ufuklar Neşriyat, 1992), 135-136.

162. Muhammet Raşit Batur, "Rabıta”, Günümüz Kelam Problemleri, ed. Recep Ardoğan (İstanbul: Klm Yayınları, 2018), 123-124.

163. Fevzi Efendi, 'Aynü’l-hakîka, 9-11.
} 
değerlendirilemeyeceğini, çünkü râbıta yapan müridin tüm derdinin Allah'a ulaşmak olduğunu; bunun namazda imama uyan birinin imamın okuduğu "Ancak sana ibadet eder ve ancak senden yardım dileriz"164 âyetine iştirak etmesi gibi değerlendirilmesi gerektiğini, cemaatle kılınan bu namazın tek başına kılınandan kat kat daha fazla sevaba, huzura ve huşûya sebep olduğunu söylemektedir. Aynı şekilde râbıtayı hacda ve Medine ziyaretindeki delile, küçük çocuğun eğitimindeki muallime benzetmektedir. ${ }^{165}$

Mustafa Fevzi, müminin halini hayra yormak, kolayca küfre nisbet etmemek gerektiğini, kolayca tekfir edenlerin Haricîler olduğunu; ${ }^{166}$ râb1tayı kabul eden bunca âlim, büyük zat varken bunu inkâr edenlerin onların yanında hükmü olmadığını; râbıta aleyhine yazan Seyyid Hoca'nın müşrikler hakkında inen âyetleri müminler için yorumladığını, kendi algısına göre âyeti tefsir ettiğini söylemektedir. ${ }^{167}$

Şeyhe râbıta hususunda padişahla görüşmek isteyenin halini misal getiren Mustafa Fevzi, padişahla görüşmek isteyen bir kişinin ya sadrazam veya padişahın hizmetçisi ile irtibata geçeceğini, bu sürede hep irtibata geçeceği kişiyi düşünüp yani ona râbıta yapıp hem de hürmet edeceğini, normalin de bu olduğunu, çünkü hizmetçisine hürmetin padişaha hürmet olduğunu; evliyanın ve mürşid-i kâmillerin de Rasûlullah'a nispetle bu konumda olduğunu; onlara yapılacak hürmet ve râbıtanın Rasûlullah’a yönelik olduğunu söylemektedir. ${ }^{168}$ Mustafa Fevzi'ye göre padişahla görüşmek için hizmetçisine hürmet eden ve ona râbıta yapan kişi nasıl küfürle itham edilemiyorsa, şeyhe râbıta yapan da küfürle itham edilemez. Çünkü hiçbir mürit şeyhi ilah tanımamakta ve ona ibadet etmemektedir. Bir mümini kolayca küfre nisbet etmemek gerekir. ${ }^{169}$

Hasan Hilmi ise ilimle uğraşanların hocalarının huzurunda ders okurken onu dinleyip sûretine baktıklarını, gıyabında ders çalışırken, kitap mütalaa ederken sanki hocalarının huzurunda okuyormuş gibi mütalaa ettiklerini, bir tür râbıta olmasına rağmen, bunun güzel görülüp övüldüğü, kimsenin buna şirk demediği halde; müritlerin, Allah’ın ahlâkı ile ahlâklanmış, 
Rasûlullah'a uyan, tevhidde fâni olmuş mürşitlerine râbıtasını kötüleyip şirkle itham etmenin hakkaniyete uygun olmadığını; ${ }^{170}$ râbıtaya haram diyen ve yapanı küfürle itham edenlerin ne Kur'ân'dan ne hadisten bir delili olmadığı gibi muteber kitaplarda da muteber râbıtanın haramlığını ifade eden bir ibarenin bulunmadığını, bazı garaz sahiplerinin bu minvaldeki sözlerinin râbıtayı bilmemekten kaynaklandığını söylemektedir. ${ }^{171}$

Hüseyin ed-Devserî, râbıtanın Allah ve Rasûlü tarafından doğrudan emredilen bir husus, bizâtihi vâcip veya müstehap olmadığını, tasavvuf ehlinden kimsenin böyle bir şey söylemediğini, müride râbıta telkin edildiğinde müridin bunu yapıp yapmamakta muhayyer olduğunu, yaparsa güzel olacağını, yapmazsa sadece bir edebi terk etmiş bulunacağını, zaten râbıtanın da mübtedi müride tavsiye edildiğini söylemektedir. ${ }^{172}$

Zâhid Kevserî (ö. 1952), yaşadığı dönemde bazılarının râbıta konusunda konuşmayı müşkil gördüklerini ancak kendisinin bu hususta bir sıkıntı görmediğini, selef ve halef ulemânın hiçbirinden râbıtayı inkâr mânâsına bir söz nakledilmediğini, hatta usûl ve fürû́da uyulan imamlardan Sadru'ş-Şerîa'nın (ö. 747/1346) "173 “Ta'dîlü̉l-ulûm” adlı eserinde râbıtanın sâlik için gereğini açıkça belirttiğini ifade etmektedir. ${ }^{174}$

Orhan Çeker, râbıtayı feyizli bir ortam veya insanı hayalen canlandırma ve hemhal olma yoluyla onlarda bulunan feyz ve nurdan istifade etme olarak târif etmiş; ibadet olmadığını ısrarla vurgulamıştır. Râbıtaya 1srarla ibadet diyenlerin bunu kasten yaptığ 1 kanaatindedir. ${ }^{175}$

Râbıtayı savunanlara göre râbıta ve muhabbet asaleten Rasûlullah'a, tebean O’nun kâmil vârislerinedir. ${ }^{176}$ Hasan Hilmi, râbıtanın gerçekte şeyhin güzel ahlâkını elde etmek için yapılıp şeyhin kendisine yapılmadığına, "eğer şeyh sırat-1 müstakimden sapar veya irtidat ederse ona olan muhabbetin buğza dönüşeceğini” delil getirmektedir. ${ }^{177}$

170. Hasan Hilmi, es-Sifrü'l-esnâ, 47.

171. Hasan Hilmi, es-Sifrül-esnâ, 105.

172. Devserî, er-Raḥmetü'l-hâhbita, 1/538.

173. Sadrüşşerîa es-Sânî Ubeydullāh b. Mes'ûd b. Tâcişşerîa Ömer b. Sadrişşerîa el-Evvel Ubeydillāh b. Mahmûd el-Mahbûbî el-Buhârî.

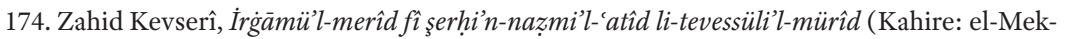
tebetü'l-Ezheriyye, ts.), 51.

175. Orhan Çeker, Tasavvufî̀ Meselelere Fıkhî Bakış (İstanbul: Rıhlekitap, 2012), 62-66.

176. Zeynüddin Hâfî, el-Veșâya'l-Ḳudsiyye (Dâru'l-Kütübü'l-Katariyye, 1065), 107-108b; Hasan Hilmi, es-Sifrü'l-esnâ, 66.

177. Hasan Hilmi, es-Sifrü’l-esnâ, 69. 
Abdülganî en-Nablûsî (ö. 1143/1731), mürşide râbıtayı savunma babında, müridin, hiçbir aracı olmadan doğrudan Rabbinin huzurunda durmasının en mükemmel olanı olduğunu inkâr etmediklerini, ancak ilmen, zevken ve vicdanen kesin bilgiyle müridin sülûkünün başlang1cında asla buna güç yetiremeyeceğini bildiklerini söylemektedir. Çünkü câhil olanların, havâtır ile maksut olan şeyleri yani şeytan ve nefisten gelen vesveselerle Allah'tan gelen ilhamları ayırt edemeyecekleri için küfre düşme tehlikeleri vardır. Mürit, ârif olup da her şeyi yerli yerince anlayana, yaratan ile yaratılandan geleni fark edene kadar bir vesileye ihtiyaç hisseder. Ancak bundan sonra vasitaya gerek kalmaz. ${ }^{178}$

Râbıtanın neden doğrudan Allah'a yapılmadı̆̆ı itirazına verilen en yaygın cevap bu minvaldedir. Belli bir alıştırma devresi olmadan, bazı şeyleri ögrrenmeden ve yaşamadan müridin buna güç yetiremeyeceği ifade edilmektedir.

\subsection{Râbıta Hakkındaki Tartışmalar Üzerine Bir Değerlendirme}

Râbıtayı şirk kabul etmek, ağır bir değerlendirmedir. Çünkü şirk, küfür gibi hususlarda genelde belirleyici olan niyettir. Râbıta yapanlar için bir niyet okumaya giderek, şeyhi tanrı yerine koyduklarını söylemek ağır bir ithamdır. Şeyhi tanrı yerine koyma, onu vesile değil de gaye edinmenin tehlikesine bizzat râbıtayı savunanlar dikkat çekmişler ve bunu kabul etmemişlerdir. Bidat olarak nitelendirebilmek için de râbıtanın ibadet olduğunun kabul edilmesi gerekir. Râbıtayı savunanlar bunu da kabul etmemişlerdir. Devserî bunu açıkça ifade etmiştir. Bir kısım benzerlikleri alıp da râbıtayı başka dinlerden alınma diyerek itham etmek de yerinde değildir. Herhangi bir uygulamanın reddedilmesi için sadece benzerlik yeterli olmaz; delillerle o uygulamanın dine uygun olmadığ ispat edilmelidir.

Râbıtayı reddedenler, râbıtayı savunmak için getirilen âyet ve hadislerin bu mânâda delil olamayacağını, başka mânâlara geleceğini iddia etmişler ancak kendileri de râbıtayı reddetmek için delâleti çok dolaylı âyet ve hadisleri getirmişler ve zorlama yorumlar yapmışlardır. Râbıtayı 
reddetmek için önce onu ibadet kategorisine girdirmişler, sonra (niyet okuması yaparak) bunun Allah'a değil şeyhe yapıldığını iddia etmişler, ardından ya bidat ya şirk veya hem bidat hem de şirk olarak damgalamışlardır. Bizzat savunanların kabul etmediği hususları, sanki onlar gizlice öyle yapıyormuş gibi iddia etmek ilmî olmadığı gibi iyi niyetle de bağdaştırılamaz. Halbuki Hanefîlerde önemli bir kaidedir: "Mümin salaha hamledilir." ${ }^{\text {"179 }}$ Bu kaide gereğince açık bir delil olmadığı müddetçe müminin günah işlemekten uzak duracağı, yaptı̆̆g işlerde İslâm'ın emirlerine uyacağ

Sıddîk Hân'ın, Şah Veliyyullah'ın (ö. 1176/1762) râbitaya karşı olduğu ifadesi de doğru değildir. Şah Veliyyullah, Nakşibendilerin Allah'a ulaştırma için üç yolları bulunduğunu, bunların zikir, murâkebe ve râbıta olduğunu söylemektedir. Râbıta için şeyhin teveccühünün kuvvetli olmasını ve daima Allah'la beraber olan (bekābillah makamında) biri olmasını şart koşan Şah Veliyyullah, müridin şeyhin sohbetinde iken şeyhin iki gözü arasına bakarak feyz almasını; şeyhten ayrı olduğu zaman da şeyhinin sûretini sevgi ve tazimle göz önüne getirmesini söylemektedir. Ona göre şeyhin sûreti sohbeti gibi fayda verir. ${ }^{180}$

Şah Veliyyullah, Sıddîk Hân'ın aktardığı ibareyi Çiş̧tiyye’ye göre “Lâ ilâhe illallâh" zikrinin yapılışını anlatırken yazmıştır. ${ }^{181}$ Burada Nakşîlerdeki râbıtaya değil de özellikle "Lâ ilâhe illallâh" zikri yapılırken Allah’tan başkasına yönelmeye, yani zikir esnasında yapılan râbıtaya karşı çıtı̆ı̆ı anlaşılmaktadır. Böyle anlaşılmadığı zaman diğer yazdıkları ile çelişki olur. Çünkü Nakşîbendilerin râbıtası haricinde Çiştiyye tarikatının usulünü yazdığı bölümde meşayihten erbaine girmenin şartlarını aktarırken bir çekince koymadan, "daima şeyhle birlikte olmaya kalbi raptetmek” şartını da saymış, ${ }^{182}$ yine çekince koymadan Çiştiyye'ye göre sâlih bir zatın kabrini ziyarette neler yapılacağını yazmış ve burada "kabir sahibinden

179. Kemâleddîn Muhammed b. İbnü'l-Hümâm, Fethu'l-kadîr 'ale'l-Hidâye (b.y.: Daru'l-Fikr, ts.), 8/259; Ebû Saîd Muhammed Hâdimî, el-Berîkatü'l-Mahmû̉diyye fî şerhi't-Ṭarîkati'l-Muhammediyye vess-şerî‘ati’n-nebeviyye fi's-sîreti'l-Ahmediyye (b.y.: Matbaatü'l-Halebî, 1348), 2/258. 180. Şah Veliyyullah ed-Dihlevî, el-Kavlü'l-cemîl fî beyâni sevâ'i's-sebîl (Medine: Camiatü'lİslâmiyye, Muhammed b. Suud el-İslâmiyye, 428), 26a-27b; Şah Veliyyullah ed-Dihlevî, el-Ḳavlü’l-cemîl \& Şifâu'l-alîl (Lahor: Mektebetü Rahmâniyye, ts.), 89-97.

181. Dihlevî, el-Kavlü’l-cemîl (Muhammed b. Suud el-İslâmiyye, 428), 24 b.

182. Dihlevî, el-Kavlü’l-cemîl (Muhammed b. Suud el-İslâmiyye, 428), 25a. 
kalbine feyz gelmesini bekler" ${ }^{\text {183 }}$ ifadesini kullanmıştır. Zaten, tasavvufî şahsiyeti ile temâyüz eden, bir medrese hocası olmasının yanında aynı zamanda bir tasavvuf şeyhi de olan, kendisini "sûfîlerin hâdimi" olarak niteleyen, Nakşibendiyye, Geylâniyye ve Çiştiyye tarikatları başta olmak üzere çeşitli tarikatlardan icazetli olan ${ }^{184}$ birisinin her çeşidi ile râbıta aleyhinde olması çok düşük bir ihtimaldir.

Genel mânâda râbıtayı savunanların delilleri reddedenlere göre çok daha güçlüdür. Osmanlı'da râbıtaya güçlü şekilde itiraz eden Seyyid Hoca bile râbıtayı tamamen reddetmemiş, zamanında yapıldığını söylediği bazı türlerine itiraz etmiştir. Tasavvufla ilgisi olan çok sayıda âlimin râbıtayı reddetmemesi, hatta önemli bölümünden onun lehine ifadeler aktarılması râbıta için önemli bir delildir. Zâhid Kevserî̀nin isabetle belirttiği gibi, râbıtayı doğrudan veya dolaylı kabul eden bunca âlim şeriat ile oynamış olamazlar. ${ }^{185} \mathrm{Bu}$ sebeple her türü ile râbıtayı reddetmek doğru bir yaklaşım değildir. Doğrusu râbıtayı tafsile tâbi tutmak ve yanlış olan hususlara karşı çıkmaktır.

\section{Râbıtanın Fıkhî Hükmü}

19. yüzyıla gelene kadar râbıtanın fikhî hükmü hakkında fıkıh kitaplarında geçen herhangi bir ifade bilinmediği gibi, tasavvufî eserlerde de böyle bir ifadeye rastlanmamaktadır. Görebildiğimiz kadarıyla râbıtanın hükmü hakkında ilk ifadeler Hâlid-i Bağdâdî̀ye aittir. Yukarıda yer aldığ 1 üzere o, risalesinde dört mezhepten hem fakih hem sûfî olarak isimlendirdiği kişilerden rivayetlerde bulunarak, dört mezhep ulemâsının râbıta hakkında ittifak ettiğini iddia etmiş, ondan sonra yazanlar da onu takip etmiştir. Ancak bu ifadelerde râbıtanın ef âl-i mükellefînden hangisine girdiğine dair bir açıklık yoktur.

Bu hususta ilk ifadeleri râbıta hakkında müstakil eser kaleme alanların ilklerinden Hüseyin ed-Devserî'de görüyoruz. O, (1237/1820)'de yazdığıı eserinde, Nakşî büyüklerinin, râbıtayı doktorun hastasına mubah

183. Dihlevî, el-Kavlü'l-cemîl (Muhammed b. Suud el-İslâmiyye, 428), 25b; Dihlevî, el-Kavlü’lcemîl-Şifâu'l-alîl, 86.

184. Ahmet Aydın, Şah Veliyyullah ed-Dihlevî ve Dihlevîlik (İstanbul: Marmara Üniversitesi, Sosyal Bilimler Enstitüsü, Doktora Tezi, 2013), 99.

185. Zahid Kevserî, İrḡāmül-merîd, 51. 
bir hususu emretmesi gibi müritlerine emrettiği, râbıtanın kalbe gelen boş düşünceleri (havâtır) defetmeye, gafleti gidermeye vesile bir husus olduğunu söylemektedir. Vâcibe ulaştıran şey vâcip, menduba ulaştıran şey mendup olduğundan kalp huzuruna ulaştırması, gafleti yok etmesi sebebiyle râbıta da menduptur. Bunun için ayrıca bir şerî delil olması gerekmez. $^{186}$

Kendisi de bir dönem Nakşibendî tarikatına bağlanan Reşid Rıza, ${ }^{187}$ sorulan bir soru üzerine verdiği cevapta, teveccüh ve râbıtanın dinden olmadığını, bunları İslâm'da konulmuş (meşrû) bir ibadet kabul etmenin câiz olmadığını, bununla birlikte bunları yapanları küfürle itham edemeyeceğini, ancak şerîi ilimleri bilmeden ve nefsin hakikatini tanımadan bu tarikatı (Nakşibendiyye) taklit edenlerin tevhidden çok putçuluğa yakın olmasından korktuğunu; bununla birlikte İslâm akidesini bilen bir müridin tevhid ile zikir esnasında şeyhini hayal etmeyi birleştirebileceğini söylemiştir. Bunun yolu olarak da "zikir yapacağı zaman sanki şeyhinin huzurunda zikrediyor, Kur’ân okuyor veya ilim tahsil ediyor gibi hayal ederek edebini gözetir, kalp huzuruna dikkat eder; bu esnada onun fayda veya zarar vereceğine inanmaz, amelinin kabulü için şeyhine değil ancak Allah'a yönelir ve Kelime-i tevhîdin mânâsını düşünürken şeyhinin sûretini hayal etmez." demektedir. Bunun müride kolay olduğunu söyleyen Rıza, râbıta ve teveccüh için şer'an istenen bir iş olarak hükmetmenin câiz olmadığını, şerî naslardan birine aykırı olmayan tecrübeye dayanan bir husus olduğunu, ${ }^{188}$ râbıtanın bir terbiye metodu kabul edilmesi gerektiğini söylemektedir. ${ }^{189}$

Kanaatimizce râbıtanın çeşitlerine göre hükümlerinin de farklı olması gerekir. Anlatıldığı şekilleriyle mürşit râbıtası denilen râbıtaya tek bir hüküm verme imkânı yoktur. Çünkü farklı şekiller ve farklı yolları anlatılmıştır:

1. Râbitayı, şeyhe muhabbet duyma ve onu örnek alma anlamında alırsak, buna mendup hükmünü vermek yanlış olmaz. Çünkü müminlerin birbirini sevmesi gerektiği, Allah için sevmenin fazileti naslarla ifade edildiği gibi; ${ }^{190}$ peygamberlerin yanında diğer sâlih zatların örnek alın-

186. Devserî, er-Rahmetü’l-hâbiṭa, 1/537; Hasan Hilmi, es-Sifrü’l-esnâ, 73.

187. Reşîd Rızâ, Fetâvâ, ed. Salahuddin el-Menced (b.y.: y.y., ts.), 2/668.

188. Reşîd Rızâ, Fetâvâ, 2/671-672 (256. Fetva).

189. Reşîd Rızâ, Fetâvâ, 2/720-723 (275. Fetva).

190. Bu konuyla ilgili iki hadis şöyledir: Bir kudsî hadiste Allah Teâlâ, "Nerede benim rızâm için birbirlerini sevenler? Gölgemden başka gölgenin bulunmadığ 1 bugün onları, kendi arşımın 
ması ile ilgili de naslar bulunmaktadır. Kur'ân-ı Kerim’de örnek olarak peygamberlerin yanında bazı sâlih zatlara da yer verilmiş; Peygamberimiz (s.a.v.) de bazı hadislerinde geçmiş dönemde yaşayan sâlih zatlardan bahsederek onların örnek alınmasını istemiştir. Mesela bunlardan birinde Peygamberimiz bir gün ashâbına: "Sizden biri, Ebû Damdam gibi olmaktan âciz midir?” diye sormuş; oradaki sahâbîler: "Ebû Damdam kimdir?” diye sorunca, Rasûlullah: "Sizden önceki kavimlerden birine mensup biriydi. 'Bana hakâret eden ve dil uzatarak gıybetimi yapan kimselere hakkımı helâl ediyorum' derdi." cevabını vermiştir. ${ }^{191}$

2. Gündelik hayatında şeyhin yanında olduğunu düş̈̈nme ve ona göre davranışlarına çekidüzen verme şeklindeki râbıtaya ise mubah hükmünü vermek daha uygundur. Çünkü kişinin herhangi bir şey yaparken yanında hürmet ettiği birini düşünüp ona göre davranmasinda bir beis yoktur. Hatta ĕger kötülüklerden bu yolla uzak kalıyorsa, emirleri de bu sayede yapıyorsa hükmü de ona göre olur. Yani kaçındı̆̆ı kötülüğ̈̈n veya yapması gereken emrin hükmüne göre vâcip bile olabilir. Burada "Allah'tan korkup da kötülükten kaçmıyor, emri yerine getirmiyor da şeyhten çekindiği için mi bunu yapıyor?” itirazı ilk bakışta yerinde görünse de iyi düşünüldüğ̈̈nde bunun insan psikolojisi ile ilgili bir husus olduğu görülür. Pek çok kişi, bir büyüğ̈̈nün hatta herhangi bir insanın yanında yapamadı̆̆ı kötülüğ̈̈ tek başına iken, aslında rahatsız olduğu halde, yapmakta; yalnızken namaz kılmayan bir kişi namaz kılan bir büyüğ̈̈nün yanında, severek ve isteyerek, namazın kılmaktadır. Her ne kadar istenen hedef, her zaman Allah'in huzurunda olduğunu bilerek davranmaksa da bu durumu başaramayan kimsenin, şeyh olsun olmasın yanında sâlih bir zatı düşünmesinde bir beis yoktur. Bu konuda Ebû Yûsuf'tan şöyle bir söz nakledilmiştir: "Benim için Basra, Kûfe ve İslâm dünyasının hiçbir yerinde Ebû Hanîfe'den daha sevgili birisi yoktur. Vallahi, onun hayali gece gündüz gözümün önündedir. Nefsimde ondan bir miktar bile ayrı kalamam."

gölgesinde gölgelendireceğim.” buyurur. bk. Müslim, Birr", 37; Tirmizî, "Zühd”, 53. Diğer hadise göre "Amellerin en faziletlisi Allah için sevmek, Allah için buğz etmektir." bk. Ebû Dâvud, Sünnet", 3 (No. 4599).

191. Ebû Dâvud, "Edeb”, 36 (No. 4887).

192. Ahmed Ferid el-Mezîdî, Cem 'u'l-mekâl fí isbâti kerâmâti 'l-evliyâ (Kahire: Dâru Âsari'lİslâmiyye Srilanka, 2006), 227. Bu söz Ahmed b. Mansûr el-Cündî el-Hanefî̀nin Tenbîhü'lezkiyâ kitabında geçmektedir. 
3. Müridin kendisini şeyhin kıyafet ve heyetinde görme, şeyhin müridin vücuduna girmesi veya müridin kendisini mürşidin vücudunda yok olduğunu düşünmesi şekillerindeki râbıta, kendisini şeyh gibi düşünme kapsamında olmalıdır. Böyle olduğunda mürit sanki, "ben şeyhimin yerinde olsa idim bu hususta nasıl davranırdım?" veya "burada şeyhim olsa idi o nasıl davranırdı?" diye düşünüp ona göre hareket etmektedir. Bu râbıtalar da bir önceki râbıtaya benzer. Müridin çeşitli olaylar karşısında vereceği tepkiyi, şeyhine göre ayarlaması demektir ki, bunda da bir beis yoktur. Çünkü bu durum da insanî bir şeydir. İnsan zaman zaman kendisini başkasının yerine koyar ve onun nasıl davranacağını düşünerek kendisi de öyle davranmaya çalışır. Bu, özellikle meşhur kimselere hayran olanlarda çok sık görülen bir durumdur. Hemen hemen dünyanın her yerinde kendisini meşhur bir kişiye şekil olarak benzeten, benzemek istediği kişi gibi davranan çok sayıda insan vardır

4. Kendisine şeyhten nur/feyz geldiğini düşünmek şeklinde yapılan râbıtaya gelince, bu râbıtayı tafsile tâbi tutmak gerekir. Kendisinden nur/ feyz alınan şeyh, mürit tarafından, ya kendisi nur kaynağı olarak kabul edilir ya da nurun/feyzin kaynağı Hakk'tır, şeyh ise nur/feyzin aktarıcısı, aracısı veya vesilesidir.

Şeyhi nurun/feyzin kaynağı gibi düşünmek sakıncalıdır. Ancak bu da tafsile ihtiyaç hissetmektedir. Eğer mürit şeyhine Hakk'ın hulûl ettiğini, bu sebeple de şeyhinin nur/feyz kaynağı olduğunu düşünürse bu şirktir. Öyle değil de Allah Teâlâ'nın şeyhine nuru/feyzi verdiğini bu sebeple onun da nur/feyz kaynağı olduğunu düşünürse, bu şirk olmaz ancak hulûl, masumiyet düşüncesi gibi hususlara kapı açma tehlikesi bulunduğundan, sedd-i zeria kaidesi gereğince câiz değildir. Şeyhi nurun/ feyzin aktarıcısı gibi görmeye yani râbıta yaparken Allah'tan gelen feyzin önce şeyhe ondan da kendine geldiğini düşünmeye, asıl kaynağın Allah olduğunun bilinmesi ve gözden kaçırılmaması, hulûl vb. düşüncelerin olmaması şartlarıyla câiz hükmü verilebilir. Buna da insan psikolojisi ile alakalı bir durum olarak bakılabilir. Belli bir seviyeye gelmemiş bir müridin doğrudan Allah’tan feyz/nur beklemeye alıştırabilmesi için böyle bir metot kullanılabilir. Ancak avam tarafından bunun ayırt edilmesi zordur. Ayrıca bunu ne zamana kadar yapacağı da belli değildir. Bir süre sonra şeyhi feyzin kaynağı görme tehlikesi belirebilir. Bu sebepten râbıtanın bu türünün herkese tavsiye edilmemesi gerekir. 
Bu hususta yetkin isimlerden biri olan Mehmet Emin Er (ö. 2013), râbıtanın aslının şeyhi çok sevmek olduğunu, şeyhi yanında gibi düşünmek mânâsına râbıtanın meşru olup şeyhin alnına yönelip ondan feyz geldiğini düşünmek ve kalben yardım isteme mânâsında râbıtanın bidat olduğunu söylemektedir. ${ }^{193}$

5. Râbıtanın çeşitleri arasında sayılan, mânevî râbıta, şeyhi yanında düşünmek kapsamındadır ve onun hükmünü alır. Özel ders râbıtası, şeyhten feyz geldiğini düşünmek kapsamındadır ve oradaki tafsilata tâbidir. Zikirden önce, sohbet ve hatmede yapılan râbıta ise zihni toparlamak, şeyhe bağlılı̆̆ı artırmak için yapılan râbıtalardır; bu sebeple onların hükmünü alır, yani mubahtır.

6. Kabirde yatan bir velî zata râbıta ise genellikle tevessül kapsamında değerlendirilmiştir. Allah Teâlâ'ya, vefat etmiş sâlih bir zatı vesile ederek dua etmek, Allah'tan o sâlih zata inen feyz ve nurdan kendisine de inmesini istemek anlamında bir tevessüle âlimlerin geneli tarafından cevaz verilmiştir. ${ }^{194}$ Bunun haricinde kabirde yatan zattan feyz gelmesi şeklinde râbıtanın yaşayan şeyhten feyz gelmesini düşünmek kapsamında değerlendirilmesi gerekir ve oradaki tafsilata tâbidir.

7. Namazda şeyhe râbıta hususu tafsilata tâbidir. Dağıstânî, kendisine sorulan, "namaz kılarken peygamberler veya velîlerden birini hatırlamak ve onları düşünmek câiz ve doğru mudur?" sorusuna; "namazın huzur ve huşûuna mâni dünyevî duygu ve düşüncelerden kurtulmak maksadıyla yapılırsa câizdir" diyerek ${ }^{195}$ cevap vermiştir. Buna delil olarak da "tahiyyat"

193. Mehmet Emin Er, "Rihle”: Tasavvuf Soruşturması", Muhammed Emin Er (10 Aralık 2020). 194. Rasûlullah'ı ve ona kıyasla da diğer salih insanları vesile ederek Allah'a dua etmenin cevazı hususunda görüş bildirenlerin bir kısmı için bk. Ebu'l-Hasen Takıyyüddîn es-Sübkî, Şifẩü’s-sekām fî ziyâreti hayri'l-enâm (Beyrut: Dâru'l-Kütübü'l-İlmiyye, 2008), 357; Ebu'l-Vefâ Burhânüddîn İbrâhîm İbn Ferhun, İrşâdü's-sâlik ilâ ef âli'l-menâsik, thk. Muhammed b. el-Hâdî (Riyad: y.y., 2002), 785, 800-801; Ahmed b. Muhammed Tahtâvî, Hâş̧iye 'alâ Merâkki'l-felâh (Beyrut: y.y., 1997), 551; Muhammed b. Şerefiddîn el-Halilî, el-Fetâvi'l-Halîlî 'ale'l-mežhebi'ş-Şâfiì ' (Tab'atü Masriyye Kadîme, ts.), 2/259; Şemsüddin Ebû Abdillah Muhammed el-Hattab er-Ruaynî, Mevâhibü'l-celîl li-şerhi Muhtașarı Halîl (Beyrut: Dâru'l-Fikr, 1992), 3/264-265; Ebû Abdullah Muhammed b. Mûsa el-Merâkeşî, Misbâhu'z-ẓalâm fî̀'l-müstegî̀îine bi-hayri'l-enâm fi'l-yakazati ve'l-menâm, haz. Muhammed Ali Şükrî (Beyrut: Dâru'l-Kütübü'l-İlmiyye, ts.), 51-53, 57-63, 92-104; Muhammed İbnü'l-Hâc el-Abderî, el-Medhal (b.y.: Dâru't-Turâs, ts.), 254-255. Ayrıca bu hususta derli toplu bilgiler için bk. Zahid Kevserî, Makālât (Kahire: y.y., 1372), 378-397; Akif Dursun, Tasavvuf Fikıh İlişkisi (İstanbul: Marmara Üniversitesi, Sosyal Bilimler Enstitüsü, Doktora Tezi, 2020), 389-401.

195. Dağıstânî, Fetvalar, 157. 
okunurken “es-selâmu 'aleyke eyyühe'n-nebiyyü” cümlesinde Rasûlullah’1 hatırlamak ve O'na selâm veriyor gibi düşünmeyi, "es-selâmu 'aleynâ ve 'alâ 'ibadillâhi’s-ṣâliḥ̂in” cümlesinde de sâlihleri hatırlamayı getirmiştir. Açıklamalarından kişinin namaz kılarken yanında sâlih bir zatın olduğunu düşünmesi, onun gibi namaz kılmaya çalışması hususlarını kastettiği anlaşılmaktadır. ${ }^{196}$ Bu mânâda Gazzâlî’nin de şöyle bir ifadesi vardır:

“Eğger sen Allah’ın celâlinin hakikatini idrak etmekten âciz isen, hiç olmazsa zamanındaki hükümdarlardan birisinin huzurunda bulunduğun gibi ol! Veya namaz boyunca farzet ki, ehlinden seni koruyup gözeten sâlih bir kimse tarafından gözetilmektesin veya seni iyi bilmesini arzu ettiğin herhangi bir insanın kontrolü altındasın. Böyle bir düşünce ile kıldığın namazda, her tarafın sükûnete kavuşur."197

Bunun haricinde namazın içinde şeyhi karşında düşünerek râbıta yapılamayacağı bizzat sûfîler tarafından da ifade edilmiştir. ${ }^{198}$ Kişinin namaz kılarken yanında sâlih bir zat olduğunu düşünerek daha dikkatli kılmaya çalışmasında bir beis yoktur ancak herhangi bir kimseyi karşısında düşünerek namaz kılmak şirke kapı aralar, çünkü sanki ona ibadet ediyormuş gibi bir durum ortaya çıkar; bu sebepten câiz değildir.

Zikir esnasında râbıtaya da bu zaviyeden bakmak gerekir. Zikir yaparken şeyhini kalbinde veya karşısında ondan feyz geliyor gibi düşünmek câiz değildir. Zikir yaparken Allah'tan başkasına yönelmemek gerekir. Bu sırada şeyhine bu şekilde râbıta yapan kişi kendi iradesi ile Allah'tan başkasına yönelmiş olur. Bunları yaparken şeyhini yanında imiş gibi düşünmekte ise beis yoktur. Namaz kılarken, zikir yaparken kalbe gelen havâtıra engel olmak için şeyhi düşünme yoluna başvurmak sağlıklı değildir. Bu esnada şeyhin kendisi de bir tür havâtır olmaktadır. Seyyid Hoca'nın dediği gibi insan elinde olmadan gelen havâtırdan sorumlu değildir; ancak kendi kastıyla gelen havâtırdan sorumludur.

8. Resme râbita hususuna gelince, râbitayı anlatan tasavvuf kaynaklarında resme râbıta ile ilgili bir ifade yer almamaktadır. Ancak bazı tarikatlarda resme/fotoğrafa râbıta yapıldığı ifade edilmektedir. ${ }^{199}$ Putperestliğin toplumca mübarek görülen zatların sûretleri ve heykelleri yapılarak 
başladığı ve Rasûlullah'ın bu husustaki sert uyarıları bilinmektedir. Her ne kadar daha sonraki dönemlerde resimle ilgili daha hafif hükümler verilse de bütün bunlar tazim olmaması ile kayıtlanmıştır. Fotoğraf ortaya çıktıktan sonra, fotoğrafın elle çizilen resimler gibi olmadığı, aynı yasak kapsamına girdirmenin uygun olmadığı söylenmişse de yine tazim olmaması şartına dikkat çekilmiştir. ${ }^{200}$ Resim yasağının sedd-i zeria kapsamında olduğunu belirten Ahmet Hamdi Akseki (ö. 1951), dinî bir tazîme vesile teşkil etmeyen ve Allah'ın yaratmasına benzetmek (teşebbüh bi-halkillah) kastı olmayan, kendisinde bir maslahat bulunan resim yapmak, fotoğraf çekmek ve bulundurmanın şerî bir mahzuru olmadığını ifade etmektedir. ${ }^{201}$ Râbıta niyetiyle yanında şeyhinin resmini/fotoğrafını taşıyan ve ona bakarak râbıta yapan kişi bunu hürmet ve tazim kastıyla yapacaktır. Bu eğer resim yani elle çizilmiş bir portre ise ulemâya göre kesin olarak haramdır. Fotoğraf ise illette ortak olmaları yani tazim kastının bulunması nedeniyle resimle aynı hükme tâbidir, yani haramdır.

\section{Sonuç}

Başta Nakşîbendiler olmak üzere çok sayıda tarikatta bilinen ve uygulanan mürşit râbıtası ilk dönemde şeyhe muhabbet duymak ve onu örnek almak olarak başlamış, daha sonra şeyhin sûretini ve ondan feyz geldiğini düşünmeye evrilmiştir. İlk zamanlarda özel bir ders olarak verilmeyip sadece belli başlı müritlere tavsiye edilirken daha sonra ilk başlayanlara verilen bir ders haline dönüşmüş, pek çok tarikat ehli tarafından seyr u sülûkün en esaslı yollarından biri kabul edilmiştir. Bu durum zamanla abartılmış, havâtırı defetmek gerekçesi ile müridin namaz ve zikir esnasında da şeyhini düşünmesini isteyenler ortaya çıkmışır. Bu da bazı âlimlerin tepkisini çekmiş ve râbıta aleyhinde söz söylemelerine, risaleler yazmalarına neden olmuştur. Râbıta aleyhine yapılan konuşmalar ve yazılan yazılar; bunlara cevap verilmek üzere risaleler, eserler yazılması sonucunu getirmiştir. Râbıta aleyhine yazılanlarda şirk, bidat gibi aşırı

200. Bu hususta geniş bilgi için bk. Heyet, İlmihal: İslâm ve toplum (İstanbul: Türkiye Diyanet Vakfı Yayınları, 2003), 2/97-105; Yıldıray Sipahi, "İstihsân Açısından Resim ve Heykel”, İslâm Hukuku Araştırmaları Dergisi 31 (2018), 509-540.

201. Ahmet Hamdi Akseki, "Resim ve Sûret Meselesi", haz. Halit Ünal, Avrupa İslâm Üniversitesi İslâm Araşttrmalart: Islamic University of Europa Journal of Islamic Research 4/1 (2011), 26. 
ifadeler yer alıp râbıta yapanlar müşrik veya bidat ehli olmakla itham edilirken, savunan eserlerde de yerinde delil ve ifadeler yanında bazen zorlama delillere de yer verilmiştir.

Bu hususta vardığımız sonuçları şöyle sıralayabiliriz:

1. Râbıtanın çok çeşitleri bulunmaktadır. Ancak özellikle konuya uzak olanlar onu genellikle tek bir anlama hasrederek yanlış veya eksik hüküm vermektedirler. Râbıtaya tek bir hüküm vermek yerine çeşitlerine göre hüküm vermek daha isabetlidir.

2. Genel mânâda râbıtanın ibadet olarak değerlendirilmesi yanlıştır. Eğer her türü ile râbıta ibadet gibi değerlendirilirse bidat veya şirk olarak damgalanmaktan kurtulamaz. Bir eğitim metodu kabul edilip terbiyeye yardımcı bir husus olarak değerlendirilmesi gerekir.

3. Râbıtanın yapılış şekline ve yerine göre hükümleri farklıdır. Buna göre şeyhe muhabbet ve onu örnek almak anlamında râbita menduptur. Hareketlerine çeki düzen vermek maksadıyla yapılan râbıta genel mânâda mubah olmakla birlikte yapılan veya kaçınılan amele göre farklı hükümler alabilir. Vâcibe götüren şey vâcip, menduba götüren şey mendup, harama götüren şey haramdır.

4. Namaz ve zikir esnasında şeyhi karşısında veya kalbinde imiş gibi düşünerek yapılan râbıta câiz değildir. Namaz kılarken veya zikir yaparken râbıta, sadece şeyh yanında imiş gibi düşünerek yapıldığında câiz olur.

5. Resme râbıta yapmak haramdır.

6. Günümüzde şeyhin sûretini ve ondan feyz geldiğini düşünme şeklinde bir râbıtaya çeşitli kesimlerden yoğun bir itiraz gelmektedir. Bu sebeple her ne kadar bunların bazı türlerine cevaz hükmü verilebilse de tüm müritlere tavsiye edilecek râbitayı şeyhe muhabbet ve onu örnek almak şeklinde; şeyhin sûretini düşünmek ve ondaki feyzden istifade etme şeklindeki râbıtayı ise bunu hakkıyla yapabileceklere tavsiye ile sınırlamanın daha uygun olacağı kanaatindeyiz. 


\section{Sufinge}

124

Çıkar Çatışması / Conflict of Interest: Yazarlar çıkar çatışması olmadığını beyan etmiştir. / The authors declared that there is no conflict of interest.

Finansal Destek / Grant Support: Yazarlar bu çalışma için finansal destek almadıklarını beyan etmiştir. / The authors declared that this study has received no financial support.

\section{Kaynakça}

Abdülkâdir Geylânî, Muhyiddîn Ebû Muhammed. Fütûhụ'l-g̉ayb. Kahire, 1973.

Ahmed b. Hanbel, Ebû Abdillâh Muhammed. el-Müsned. thk. Şuayb Arnavud vd. 45 Cilt. Beyrut: Müessesetü'r-Risâle, 1421/2001.

Akseki, Ahmet Hamdi. "Resim ve Sûret Meselesi”. haz. Halit Ünal. Avrupa İslâm Üniversitesi İslâm Araştırmalart = Islamic University of Europa Journal of Islamic Research 4/1 (2011), 21-27.

Âlûsî, Ebü's-Senâ Şihâbüddîn Mahmûd. el-Feyżü'l-vârid 'alâ ravżi Mersiyyeti Mevlânâ Hâlid. thk. Ahmed Ferid el-Mezîdî. Beyrut: Dâru'l-Kütübü’l-i̇lmiyye, 2010.

Abderî, Muhammed İbnü'l-Hâc. el-Medhal. 4 Cilt. Dâru't-Turâs: y.y., ts.

Arslan, Sevim. "Muhabbet Râbıtası". Eskişehir Osmangazi Üniversitesi İlahiyat Fakültesi Dergisi 2/3 (30 Aralık 2015), 49-70.

Arvâsî, Abdülhakim. Râbıta-i Şerife. İstanbul, 1976.

Ateş, Süleyman. İslâm Tasavvufu. İstanbul: Yeni Ufuklar Neşriyat, 1992.

Aydın, Ahmet. Şah Veliyyullah ed-Dihlevî ve Dihlevîlik. İstanbul: Marmara Üniversitesi Sosyal Bilimler Enstitüsü, Doktora Tezi, 2013.

Aydın, Ferit. Tarikatta Rabıta ve Nakşibendilik. İstanbul: Süleymaniye Vakfı Yayınları, 2000.

Batur, Muhammet Raşit. "Rabıta”. Günümüz Kelam Problemleri. ed. Recep Ardoğan. 115-124. İstanbul: Klm Yayınları, 2018.

Bayındır, Abdülaziz. Kur'ân Işı̆ğnda Tarikatçllğga Bakış. İstanbul: Süleymaniye Vakfı Yayınları, 2015. Buhârî, Muhammed b. İsmail. el-Câmi'u'ṣ-șahîhh. nşr. Muhammed Züheyr b. Nasr. 8 Cilt. b.y.: Dâru Tavki'n-Necât, 2. Basım, 1422/2001.

Buhârî, Muhammed b. İsmâîl. el-Edebül'-müfred. thk. Samir b. Emin. Riyad: Dâru'l-Meârif, 1998. Cebecioğlu, Ethem. Tasavvuf Terimleri ve Deyimleri Sözlü̆ğü. İstanbul: Anka Yayınları, 2005. Cevdet Paşa, Ahmed. Tezâkir. haz. Cavid Baysun. 4 Cilt. Ankara: Türk Tarih Kurumu Yayınları, 1991.

Cürcânî, Seyyid Şerîf. Şerḥu'l-Mevâkıłf. haz. Mahmud Ömer ed-Dimyâtî. 8 Cilt. Beyrut: Dâru'lKütübü'l-İlmiyye, 1998.

Çeker, Orhan. Tasavvufî̀ Meselelere Fikhî Bakış. İstanbul: Rihlekitap, 2012.

Dağıstânî, Ömer Ziyâeddin. Tasavvufve Tarikatlarla İlgili Fetvalar. çev. İrfan Gündüz - Yakup Çiçek. İstanbul: Seha Neşriyat, 1986. 
Dağistânî, Hasan Hilmi el-Kahî. es-Sifrü'l-esnâfi'r-râbıtati’l-hüsnâ. thk. Abdülcelil 'Atâ. Dımeşk: Dâru'n-Nu'man, 1418/1998.

Devserî, Hüseyin. er-Raḥmetü’l-hâbita fi tahkîik’ir-râbiṭa (Mektûbat'in birinci cildinin sonunda). İstanbul: y.y., ts.

Dihlevî, Şah Veliyyullah,. el-Ḳavlü’l-cemîl fî beyâni sevâ'i’s-sebîl. Medine: Camiatü'l-İslâmiyye, Muhammed b. Suud el-İslâmiyye, 428, 1a-51b.

Dihlevî, Şah Veliyyullah. el-Ḳavlü’-cemîl \& Şifâu’l-alîl. Lahor: Mektebetü Rahmâniyye, ts.

Dursun, Akif. Tasavvuf Fıkıh İlişkisi. İstanbul: Marmara Üniversitesi, Sosyal Bilimler Enstitüsü, Doktora Tezi, 2020.

Ebû Dâvud, Süleyman b. Eş’as b. İshak. Sünenu Ebû Dâvud. 4 Cilt. Beyrut: el-Mektebetü’lAsriyye, ts.

Ebû Hanîfe, Nu‘mân b. Sâbit. el-Fıkhü’l-ebsat. İmârât: Mektebetü’l-Furkan, 1419/1999.

Ebû Hanîfe, Nu'mân b. Sâbit. İmam-ı Azam’ın Beş Eseri. çev. Mustafa Öz. İstanbul: Kalem Yayıncılık, 1981.

Er, Mehmet Emin. “RIHLE: Tasavvuf Soruşturması”. Muhammed Emin Er. 10 Aralık 2020. http://muhammedeminer.tekcatiegitim.org/2020/04/29/rihle-tasavvuf-sorusturmasi/

Eraydın, Selçuk. Tasavvufve Tarikatlar. İstanbul: Marifet Yayınları, 1984.

Ferrâ, Yahyâ b. Ziyâd. Meâni'l-Kur'ân. thk. Ahmed Yûsuf Necâtî vd. 3 Cilt. Kahire: Dâru’lMisriyye, 1955.

Fevzi Efendi, Edirne Müftüsü Mehmed. Aynü’l-hakîka fî râbıtati’t-tarîka. b.y.: y.y., ts.

Gazzâlî, Ebû Hâmid. İhyâu ulûmi’d-dîn. 4 Cilt. Beyrut: Dârü'l-Ma'rife, ts.

Gökbulut, Süleyman. “Cüneyd'in Sekiz Şartı”. Dokuz Eylül Üniversitesi İlahiyat Fakültesi Dergisi 2/36 (2012), 201-231.

Gündüz, İrfan. “Tasavvufî Bir Terim Olarak Râbıta”. Tasavvuf İlmî ve Akademik Araştırma Dergisi 19 (2007), 23-53.

Hâdimî, Ebû Saîd Muhammed. el-Berîkatü’l-Maḥmûdiyye fî şerhị'ț-Ṭarîkati’l-Muhammediyye ve'ş-şerî‘ati’n-nebeviyye fi's-sîreti'l-Ahmediyye. 4 Cilt. b.y.: Matbaatü'l-Halebî, 1348.

Hâdimî, Ebû Saîd Muhammed. er-Risâletü’n-Nakşibendiyye. Balıkesir, Balıkesir İl Halk Kütüphanesi, $10 \mathrm{Hk} 369 / 6,113 \mathrm{~b}-117 \mathrm{a}$.

Hâfî, Ebû Bekr Zeynüddîn Muhammed. el-Veșâya'l-Ḳudsiyye. Katar: Dâru'l-Kütübü'l-Katariyye, $5 / 1 / 1065,88 \mathrm{a}-123 \mathrm{a}$.

Hâlid el-Bağdâdî. er-Risâletü'l-Hâlidiyye fî̀r-râbitati’n-Nakşîbendiyye (es-Sifrü’l-Esnâ kitabının son tarafinda). thk. Abdülcelil ‘Atâ. Dımeşk: Dâru’n-Nu’man, 1418/1998.

Hâlid el-Bağdâdî. Halidiyye Risalesi. çev. A. Suat Demirtaş. İstanbul: Semerkand Yayınları, 2010.

Hâlid el-Bağdâdî. Risâle fî̀r-Râbıta. Ankara: Milli Kütüphane, Yazmalar Koleksiyonu, 06 MK. Yz. A $6129 / 9,53$. 


\section{Sufive}

126

AkifDURSUN

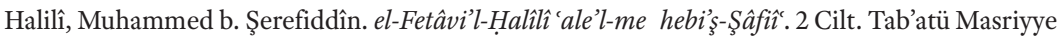
Kadîme, ts.

Hamevî, Ebü'l-Abbâs Şihâbüddîn Ahmed b. Muhammed. Nefehâtü'l-kurb ve'l-ittișâl bi-ișbâti'ttașarrufli-evliyâ'illâhi ve’l-kerâmeti ba'de'l-intikāl. Kahire: Dâru Cevâmii'l-Kelim, ts.

Hânî, Muhammed b. Abdullah. Âdâb. çev. Ali Hüsrevoğlu. İstanbul: Erkam Yayınları, 1985.

Hânî, Muhammed b. Abdullah. el-Behcetü's-seniyye fî̀ âdâbi't-tarîkati'l-'aliyyeti'l-Hâlidiyyeti'n-

Nakşibendiyye. İstanbul: Hakikat Kitabevi, 2016.

Haydârî, Fasîhuddîn İbrâhîm b. Sıbgatillâh. el-Mecdü't-tâlid fî menâkıbişşş̧eyh Hâalid. İstanbul: Matbaa-i Âmire, 1292-1875.

Heyet. İlmihal: İslâm ve toplum. İstanbul: Türkiye Diyanet Vakfı İslâm Araştırmaları Merkezi, 2003. Heytemî, Ahmed b. Muhammed İbn Hacer. ed-Dürrü'l-mendûd fi's-șalât ve's-selâm 'alâ șâhibi'lmakāmi’l-mahmûd. Cidde: Dâru'l-Minhâc, 1426.

Hüseyin Avnî. "Râbıtanın Şeri Delilleri”. Darusselam. 5 Kasım 2020. https://darusselam.com/ reddiyeler/rabtann-eri-delilleri.html\#_ftn61

Irâkī, Ebü'l-Fazl Zeynüddîn Abdürrahîm. el-Muginî 'an hamli’l-esfâr fi'l-esfâr fî̀ tahrîci mâ fi'lİhyẩi mine’l-ahbâr. 7 Cilt. Riyad: Dâru'l-Âsime, 1408/1987.

Isfahânî, Ebû Nuaym. Hilyetül-evliya ve tabakātü'l-asfiyâ'? 10 Cilt. Beyrut: Dâru'l-Kütübü'lİlmiyye, 1988.

İbn Adî, Ebû Ahmed Abdullāh. el-Kâmil fî du'afầ'irr-ricâl. thk. Âdil Ahmed - Ali Muhammed. Beyrut: el-Kütübü'l-İlmiyye, 1418/1997.

İbn Atâullah el-İskenderî. Miftâhu'l-felâh ve mișbâhu'l-ervâh. Mısır: Matbaatüs-Saâde, ts.

İbn Ferhun, Ebu'l-Vefâ. Burhânüddîn İbrâhîm. İrşâdửs-sâlik ilâ ef âli'l-menâsik. thk. Muhammed b. el-Hâdî. 2 Cilt. Riyad: y.y., 2002.

İbn Hacer el-Askalânî. el-İsâbe fî temyîzi'ș-ṣahâabe. thk. Adil Ahmed. Ali Muhammed. 8 Cilt. Beyrut: Dâru'l-Kütübü'l-İlmiyye, 1415.

İbn Hibbân, Ebû Hâtim Muhammed. Kitâbü'l-mecrûhîn mine'l-muhaddișin ve'd-ḍu'afầ' ve'lmetrûkin. thk. Mahmud İbrâhim Zâyid. 3 Cilt. Haleb: y.y., 1396.

İbn Kayyim el-Cevziyye. Kitâbu'r-Rûh. Beyrut: Dâru'l-Kütübü'l-İlmiyye, ts.

İbn Mâce, Ebû Abdillâh Muhammed. Sünenü İbn Mâce. thk. Muhammed Fuad Abdülbakî. 2 Cilt. Dâru İhyâi Kütübü'l-Arabî, ts.

İbn Manzûr, Ebu'l-Fazl Muhammed b. Mükerrem. Lisânül'-'Arab. 15 Cilt. Beyrut: Dâru Sadır, 1414. İbn Teymiyye, Ebü'l-Abbâs Takıyyüddîn Ahmed. Mecmûu'l-Fetâvâ. thk. Abdurrahman b. Muhammed. Medine: Mecmeu'l-Melik, 1416-1995.

İbnü’l-Cevzî, Ebü’l-Ferec. el-Mevżû́ât. 3 Cilt. Medine: el-Mektebetü’s-Selefiyye, 1386/1966. İbnü'l-Hümâm, Kemâleddîn Muhammed b. 'Abdilvâhid es-Sivâsî. Fethu'l-Kadîr 'ale'l-Hidâye. 10 Cilt. Daru'l-Fikr: y.y., ts.

İbnü’s-Sıddîk, Ebü'l-Feyz. Alî b. Ebî Tâlib imâmüll-'ârifînn. Kahire: Matbaatü’s-Seâde, 1389/1969. 
İmam Rabbânî. Mektubât-ı Rabbânî. çev. Talha Hakan Alp vd. 3 Cilt. İstanbul: Yasin Yayınevi, 2004.

İzmirli, Betül. “Kuşadalı İbrâhim Halvetî’nin Râbıta Hakkındaki Görüşleri”. AKADEMİAR Akademik İslâm Araştırmaları Dergisi 7 (Aralık 2019), 89-116.

Kaplan, Hayri. “Şa'rânî”. Türkiye Diyanet Vakfi İslâm Ansiklopedisi. 38/347-350. İstanbul: TDV Yayınları, 2010.

Karaman, Hayrettin vd. Kur'ân-ı Kerim ve Açıklamalı Meali. Ankara: Türkiye Diyanet Vakfı Yayınları, 1993.

Köle, Bekir. Zeynüddin Hâfî Hayatı Eserleri Tasavvuf Anlayışı ve el-Vasâya'l-Kudsiyye Adlı Eserinin Tahkîki. Ankara: Ankara Üniversitesi, Sosyal Bilimler Enstitüsü, Yüksek Lisans Tezi, 2001. Kürdî, Muhammed Emîn. Tenvîru’l-kulûb. Haleb: Dâru'l-Kalem, 1411/1991.

Merâkeşî, Ebû Abdullah Muhammed b. Mûsa. Misbâhhu'z-zalâm fì'l-müstegî̀̂îine bi-hayri'l-enâm fi'l-yakazative’l-menâm. haz. Muhammed Ali Şükrî. Beyrut: Dâru'l-Kütübü'l-İlmiyye, ts. Mezîdî, Ahmed Ferid. Cem'u'l-mekâl fî̀ isbâti kerâmâti’l-evliyâ. Kahire: Dâru Âsari'l-İslâmiyye, Srilanka, 2006.

Mirfet bt. Kâmil b. Abdillah. “er-Râbițatü’n-Naḳşibendiyye”. Havliyye Külliyeti’d-Dirâsâti’lİslâmiyye el-'Arabiyye li'l-Benât İskenderiye 34/5 (Aralık 2018), 1091-1130.

Mustafa Fevzi. Kitab-ı isbâtü’l-mesâlikfi râbıtati’s-sâlik. İstanbul: y.y.,1324/1906.

Müslim b. el-Haccâc. el-Câmi‘u’ṣ-șaḥ̂hh. nşr. Muhammed Fuâd Abdülbâkī. Kahire: y.y., 1374-75/1955-56.

Nablusî, Abdülganî b. İsmâîl. Miftâhu'l-ma'iyye fî țarîki’n-Nakşibendiyye. thk. Cevdet Muhammed. Kahire: ed-Dâru'l-Cevdiyye, 1429/2008.

Necmeddîn-i Kübrâ, Ebü'l-Cennâb. Fevâ’iḥu'l-cemâl ve fevâtiḥu'l-celâl. thk. Yusuf Zeydan. Kahire: Dâru Suâd es-Sabâh, 1993.

Nîsâbûrî, Ebû Abdillâh Muhammed b. Hâkim. el-Müstedrek 'ale’ș-Ṣaḥ̂hhayn. thk. Mustafa Abdülkādir Atâ. 4 Cilt. Beyrut: Dâru'l-Kütübü’l-İlmiyye, 1411/1990.

Okudan, Rıfat. “İnsanî Bir İnsiyak Olarak Râbıta”. Tasavvuf: İlmî ve Akademik Araştırma Dergisi 4/10 (2003), 201-218.

Öngören, Reşat. “Zeynüddin el-Hâfî”. Türkiye Diyanet Vakfi İslâm Ansiklopedisi. 44/375-377. İstanbul: TDV Yayınları, 2013.

Pakiş, Yahya el-Abbas el-Hâşimî. Râbıta Risâlesi. çev. Süleyman Taş. İstanbul: Buhara Vakfı, 1997. Ramazanoğlu, Mahmud Sâmi. Musâhebe. İstanbul: Erkam Yayınları, 1983.

Râzî, Ebû Abdillâh Muhammed Kutbüddin. Şerḥu Mețâli'i’l-envâr (Şerif Cürcânî talikatı ile). nşr. Zevi’l-Kurbâ. 2 Cilt. Kum: y.y., 1394.

Râzî. Fahreddin. Mefâtîhu’l-ġayb: et-Tefsîüll-kebî). 32 Cilt. Beyrut: Dâru İhyâi’t-Turâsi'l-Arabî, 1420. Reşî̀d Rızâ. Fetâvâ. ed. Salahuddin el-Menced. 6 Cilt. b.y.: y.y., ts.

Ruaynî, Şemsüddin Ebû Abdillah Hattab. Mevâhibü’l-celîl li-şerhị Muhtașarı Halîl. 6 Cilt. Beyrut: Dâru'l-Fikr, 1992. 


\section{Sufinge}

128

AkifDURSUN

Safiyyüddin, Mevlâna Ali b. Hüseyin. Reşahat Ayn-el Hayat: Can Damlaları. sad. Necip Fazıl Kısakürek. İstanbul: Eser Kitabevi, 1978.

Sefîrî, Şemsüddîn Muhammed b. Ömer. el-Mecâlisü’l-va'ziyye fî şerhi ehâdîsi hayri'l-beriyye min Sahîhi'l-İmâmi'l-Buhârî. thk. Ahmed Fethi Abdurrahman. 3 Cilt. Beyrut: Dâru'lKütübü'l-İlmiyye, 2004.

Selvi, Dilaver. Tasavvuf Metodu Olarak Rabıta. İstanbul: Semerkand Yayıncılık, 2016.

Seyyid Hoca, Hâfız. Şerhü Risâle ibtâli’r-râbıta. Manisa İl Halk Kütüphanesi, Akhisar Zeynelzade, 45 Ak Ze 1518/1, 1b-8a.

Sıddîk Hasan Han, Ebü't-Tayyib Muhammed Bahâdır el-Kannevcî. et-Tâcü'l-mükellel min cevâhiri me'âsisiri't-țrazi'l-âhiri ve'l-evvel. Katar: Vezâretü'l-Evkâf, 2007.

Sipahi, Yıldıray. “İstihsân Açısından Resim ve Heykel”. İslâm Hukuku Araştırmaları Dergisi 31 (2018), 509-540.

Sübkî, Ebu'l-Hasen Takıyyüddîn. Şifầü’s-sekām fî ziyâreti hayri'l-enâm. Beyrut: Dâru'l-Kütübü'lİlmiyye, 2008.

Sühreverdî, Ebû Hafs Şihâbüddîn Ömer. Avârifu'l-Meârif. 2 Cilt. Kahire: Dâru'l-Meârif, ts. Sühreverdî, Ebû Hafs Şihâbüddîn Ömer. Avarifü'l-Meârif: Gerçek Tasavvuf. çev. Dilaver Selvi. İstanbul: Semerkand Yayınları, 2010.

Süyûtî, Ebî Bekr b. Muhammed. Câmi'u'l-ehâdî̀. 13 Cilt. Misır: y.y., 1423/2002.

Süyûtî, Ebî Bekr b. Muhammed.. el-Hâvî̀ li’l-fetâvî. 2 Cilt. Beyrut: Dâru'l-Fikr, 1424/2004.

Şarânî, Ebü'l-Mevâhib Abdülvehhâb. el-Envârül-kudsiyye fî beyâni kavấidi's-șufiyye. thk. Taha Abdulbâki Surûr - Muhammed Abduşşâfî'. 2 Cilt. Beyrut: Mektebetü'l-Meârif, 1988.

Taberânî, Ebü'l-Kāsım. el-Mu'cemü'l-kebîr. thk. Hamdi Abdulmecid es-Selefî. Kahire: Mektebetü İbn Teymiye, 1405.

Taberî, Ebû Ca'fer. Câmi'u'l-beyân 'an te'vîli âyi'l-Kur'ân. thk. Ahmed Muhammed Şâkir. 24 Cilt. Beyrut: Müessesetü’r-Risâle, 2000.

Tahtâvî, Ahmed b. Muhammed. Hâşsiye 'alâ Merâkiłl-felâh. Beyrut, 1997.

Taşpınar, Kadir. Tasavvufta Mürşid Rabıtası. Rize: Recep Tayyip Erdoğan Üniversitesi, Yüksek Lisans Tezi, 2010.

Tirmizî, Ebû Abdillâh Muhammed Hakîm. Nevâdirül'-usûll fî ma'rifeti ahbâri'r-Resûl. thk. Abdurrahman Umeyre. 4 Cilt. Beyrut: Dâru'l-Cîl, ts.

Tirmizî, Ebû Îsâ Muhammed. el-Câmi ưl'-Kebîr: Sünen-i Tirmizî. 5 Cilt. Mısır: Mustafa Bâbi'lHalebî, 1975.

Tirmizî, Ebû Îsâ Muhammed. eş-Şemâilü'l-Muhammediyye. Beyrut: Dâru İhyâi't-Turâs, ts. Tosun, Necdet. "Râbıta". Türkiye Diyanet Vakfi İslâm Ansiklopedisi. 34/378-379. İstanbul: Türkiye Diyanet Vakfi Yayınları, 2007.

Tosun, Necdet. Bahaeddin Nakşbend: Hayatı, Görüşleri, Tarikatı. İstanbul: İnsan Yayınları, 6. Basım, 2015. 
Wilson, M. Brett. "Binding with a Perfect Sufi Master: Naqshbandī Defenses of rābiṭa from the Late Ottoman Empire to the Turkish Republic”. Die Welt des Islams 60/1 (12 Mart 2020), 56-78. https://doi.org/10.1163/15700607-00600A02

Yağcı, Hızır. “Sefîrî ve Buhârî Şerhi”. Diyanet İlmi Dergi: Diyanet İşleri Reisliği Yilliğg 54/3 (2018), 39-57.

Yavuz, Yusuf Şevki. “Âlûsî, Nu'mân b. Mahmûd”. Türkiye Diyanet Vakfı İslâm Ansiklopedisi. 2/549-550. İstanbul: TDV Yayınları, 1989.

Yıldırım, Ahmet. Tasavvufun Temel Öğretilerinin Hadislerdeki Dayanakları. Ankara: TDV Yayınları, 2009.

Yüce, Abdulhakim. “Mevlanâ Halid Bağdadî’ye Göre Şeyh-Mürid İlişkisi ve Rabıta”. Uluslararası Mevlana Halid-i Bağdadi Sempozyumu Bildirileri. ed. Erdal Baykan - Mehmet Keskin. 643-658. Ankara: Yüzüncü Yıl Üniversitesi İlahiyat Fakültesi - Van İl Müftülüğü, 2012.

Zâhid Kevserî. İġāmüll-merîd fî̀ şerhịn-naẓmi'l-'atîd li-tevessüli’l-mürîd. Kahire: el-Mektebetü'lEzheriyye, ts.

Zâhid Kevserî. Makâlât. Kahire: y.y., 1372.

Zebîdî, Ebu'l-Feyz Muhammed Murtazâ. Tâcu'l-'arûs min cevâhiri'l-Kâmûs. 20 Cilt. Beyrut: Dâru'l-Fikr, 2005.

Zeccâc, Ebû İshak İbrahim. Meâni'l-Kur'ân ve i'râbuhû. Beyrut: y.y., 1988.

Zemahşerî, Ebü’l-Kāsım Mahmûd b. Ömer. el-Keşşâf'an hakāàiḳı gavâmiżi’t-tenzîl ve 'uyûni’lekâ̄vîl fî̀ vücûhi't-te’vîl. 4 Cilt. Beyrut: Dâru'l-Kitâbi'l-Arabî, 1407. 
Sufine

130

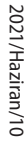

